\title{
Review:
}

\section{Therapeutic radionuclides in nuclear medicine: current and future prospects}

\author{
Chai-Hong YEONG ${ }^{\dagger 1}$, Mu-hua CHENG ${ }^{2}$, Kwan-Hoong $\mathrm{NG}^{\dagger \ddagger 1}$ \\ ( ${ }^{1}$ Department of Biomedical Imaging \& University of Malaya Research Imaging Centre, Faculty of Medicine, \\ University of Malaya, Kuala Lumpur 50603, Malaysia) \\ ( ${ }^{2}$ Department of Nuclear Medicine, the Third Affiliated Hospital, Sun Yat-Sen University, Guangzhou 510630, China) \\ †E-mail: chyeong@um.edu.my; ngkh@ummc.edu.my \\ Received May 7, 2014; Revision accepted Aug. 11, 2014; Crosschecked Sept. 25, 2014
}

\begin{abstract}
The potential use of radionuclides in therapy has been recognized for many decades. A number of radionuclides, such as iodine-131 $\left({ }^{131} \mathrm{I}\right)$, phosphorous-32 $\left({ }^{32} \mathrm{P}\right)$, strontium-90 $\left({ }^{90} \mathrm{Sr}\right)$, and yttrium-90 $\left({ }^{90} \mathrm{Y}\right)$, have been used successfully for the treatment of many benign and malignant disorders. Recently, the rapid growth of this branch of nuclear medicine has been stimulated by the introduction of a number of new radionuclides and radiopharmaceuticals for the treatment of metastatic bone pain and neuroendocrine and other malignant or non-malignant tumours. Today, the field of radionuclide therapy is enjoying an exciting phase and is poised for greater growth and development in the coming years. For example, in Asia, the high prevalence of thyroid and liver diseases has prompted many novel developments and clinical trials using targeted radionuclide therapy. This paper reviews the characteristics and clinical applications of the commonly available therapeutic radionuclides, as well as the problems and issues involved in translating novel radionuclides into clinical therapies.
\end{abstract}

Key words: Therapeutic radionuclide, Targeted radionuclide therapy, Radioimmunotherapy, Molecular targeting, Theranostics

doi:10.1631/jzus.B1400131

Document code: A

CLC number: R815; R817

\section{Introduction}

The history of radionuclide therapy can be traced back to the early 1900 s, after the discovery of radioactivity by Henri Becquerel and Marie Curie. In 1901, Becquerel experienced some severe inflammation of his skin after placing a tube of radium in his waistcoat pocket for several hours. This discovery led to the first use of radium in therapy when Henri Alexandre Danlos and Eugene Bloch placed radium in contact with a tuberculous skin lesion. In 1903, Alexander Graham Bell suggested placing sources containing radium in or near tumours, and in 1913, Frederick Proescher published the first study on the intravenous

\footnotetext{
\$Corresponding author

(C) Zhejiang University and Springer-Verlag Berlin Heidelberg 2014
}

injection of radium for therapy of various types of diseases (MacKee, 1921).

In the last twenty years, radionuclide therapy has been widely used in various clinical malignant and pain management applications (Hoefnagel, 1991; 1998; Nakabeppu and Nakajo, 1994; vande Streek et al., 1994; Forrer et al., 2006; Williams et al., 2008; Lambert et al., 2010; Nestor, 2010; Chiacchio et al., 2011; Ersahin et al., 2011; Carrasquillo et al., 2012; Ezziddin et al., 2012; Gabriel, 2012; Gulenchyn et al., 2012; Dash et al., 2013; Sainz-Esteban and Baum, 2013). Radionuclide therapy has the advantage of delivering a highly concentrated absorbed dose to the targeted tumour while sparing the surrounding normal tissues. In addition, the selective ability of radionuclide therapy is advantageous in the treatment of systemic malignancy, such as in bone metastases, 
where whole body irradiation using external beam radiotherapy is impossible. Since the administration of radionuclides is minimally invasive and the duration of treatment is shorter than chemotherapy, targeted radionuclide therapy has become one of the most preferred types of cancer therapy.

This paper reviews the unique characteristics and current applications of targeted radionuclide therapy, as well as future prospects including the problems and issues involved in the translation of novel targeted radionuclide therapies into clinical practice.

\section{Clinical requirements and choice of radio- nuclide for therapy}

We need to evaluate every radionuclide or radiopharmaceutical for its suitability for clinical usage. The requirements for a therapeutic radionuclide may be divided into two main categories, namely physical and biochemical characteristics (Hoefnagel, 1991). The considerations for physical characteristics include the physical half-life, type of emissions, energy of the radiation(s), daughter product(s), method of production, and radionuclide purity (Troutner, 1987; Hoefnagel, 1991; Volkert et al., 1991). The biochemical aspects include tissue targeting, retention of radioactivity in the tumour, in vivo stability, and toxicity (Zweit, 1996; Kassis and Adelstein, 2005).

The most important factor to be considered when choosing a suitable radionuclide for therapy is the effective half-life, which is the net half-life considering both physical half-life $\left(T_{\mathrm{p}}\right)$ and biological half-life $\left(T_{\mathrm{b}}\right)$ within the patient's body or organs. The determination of effective half-life $\left(T_{\mathrm{e}}\right)$ is explained in the medical internal radiation dosimetry (MIRD) calculation method, which is summarized as $T_{\mathrm{e}}=$ $T_{\mathrm{p}} T_{\mathrm{b}} /\left(T_{\mathrm{p}}+T_{\mathrm{b}}\right)$ (Toohey et al., 2000). The physical half-life is readily available from published radionuclide data (Weber et al., 1989), but the biological half-life requires knowledge of the radiotracer's spatial and temporal distribution within the body. This includes radiotracer delivery, uptake, metabolism, clearance, and excretion within the patient's body.

A suitable range of the physical half-life for therapeutic radionuclides is between $6 \mathrm{~h}$ and $7 \mathrm{~d}$ (Qaim, 2001). A very short physical half-life limits the delivery flexibility and is very impractical, while a long half-life will retain the radiation dose in the patients and expose surrounding people for a longer period. When the physical half-life is too long, patients need to be admitted and isolated for a longer period, hence increasing the treatment costs. On the other hand, the biological half-life depends on the tracer used. If the tracer is designed to be retained within the patient permanently, the physical half-life should not be too long. In addition, the tracer should have sufficient retention so that radiation can be delivered to the tumour efficiently. If the biological half-life is too short, the radionuclide will be discharged with a significantly high activity, resulting in the need for extensive radioactive waste management. Therefore, for an efficient radiation delivery, a balanced optimal biological and physical half-life should be chosen, which results in an optimal effective half-life. This consideration is best made primarily according to the type of tumour to be treated, method of administration, and uptake mechanism. If the uptake is slow, a radionuclide with a relatively long physical half-life should be used so that the radionuclide will not decay completely before it reaches the targeted tumour.

For therapeutic purposes, radiations with highlinear energy transfer (LET), such as $\alpha$ - and $\beta$-particles, are preferable. These types of particulate radiations allow very high ionisation per length of travel. Therefore, they are fully deposited within a small range of tissue (usually in $\mathrm{mm}$ ). This also reduces the need for additional radiological protection as the radiation will not penetrate through the patient's body. However, some $\beta$-emitting radionuclides also decay with $\gamma$-radiation. This associated $\gamma$-radiation could be advantageous if the energy and intensity are within the diagnostic range, as it provides the ability to visualise distribution of the radiopharmaceutical within the patient's body using gamma scintigraphy methods. Depending on the type of tumour, the energy and intensity of the emitted radiation should be chosen so that the energy and intensity of non-penetrating radiation (i.e., $\alpha$ - and $\beta$-particles) are high enough compared with the penetrating radiation (i.e., $\gamma$-radiation, X-rays, or Äuger electrons), if present. Radionuclides that emit energetic $\alpha$ - or $\beta$-particles are preferred for the treatment of bulky tumours. However, for the treatment of small clusters of cancer cells or small tumour deposits, 
radionuclides that emit Äuger electrons are considered to be more beneficial because of their high-level cytotoxicity and short-range biological effectiveness (Ersahin et al., 2011).

The other factor to be considered is the daughter product of the radionuclide. An ideal radiopharmaceutical should be able to decay into a stable daughter product such as ${ }^{153} \mathrm{Sm}$, which fully decays into stable ${ }^{153} \mathrm{Eu}$. Even if the daughter product is slightly unstable, it should at least be short-lived and may eventually decay within hours into a stable product. However, if the daughter nuclide is not stable, it may contribute to the total amount of absorbed dose. Therefore, we need to consider the percentage of dose delivered from the daughter nuclide so that it will not affect the treatment plan.

For biochemical characteristics, a clinically suitable tracer should provide selective concentrations and prolonged retention in the tumour, while maintaining minimum uptake in the normal tissue (Qaim, 2001). Furthermore, depending on the mechanism of selective uptake of the tumour either by bone deposition, protein binding, or metabolic uptake, the ratio of the radiopharmaceutical's concentration on the tumour to that of other organs or tissues should be as high as possible, so that the radiation can be delivered optimally while minimizing the radiation dose delivered to the normal tissues.

If a tracer is a proteinaceous type, it is necessary to ensure that it is stable enough during administration and is maintained in vivo long enough for sufficient radiation delivery within the patient's body before being metabolised and eventually excreted. The other factor to be considered is the size of the tracer particles. For example, in the radioembolization of liver tumours using ${ }^{90} \mathrm{Y}$-microspheres, the particles should be large enough so that they will not pass through the capillary bed into other organs, especially the lungs, and at the same small enough so that they will be able to penetrate deep inside the tumour vascularity. Therefore, the typical size for ${ }^{90} \mathrm{Y}$ radioembolization particles is between 20 and $40 \mu \mathrm{m}$ (Houle et al., 1989; Thamboo et al., 2003; Arslan et al., 2011; Kucuk et al., 2011). Other biochemical characteristics that need to be considered include low toxicity, the specific gravity for optimal flow and distribution during administration, the appropriate $\mathrm{pH}$, and the optimal clearance rate (except for permanent tracer).
Table 1 shows a summary of the physical characteristics of the commonly available therapeutic radionuclides.

\section{Selected therapeutic radionuclides and their clinical applications}

Various radionuclides have been discovered or developed for therapeutic purposes since the first use of radium in the early 1900s. The most commonly used therapeutic radionuclide today is iodine-131 labelled with sodium iodide $\left({ }^{131} \mathrm{I}-\mathrm{NaI}\right)$ in capsule or liquid form. The treatment is widely known as radioactive iodine (RAI) therapy, which uses ${ }^{131}$ I to treat thyroid-related diseases such as Graves' disease, solitary hyper-functioning nodule, and toxic multinodular goiter. RAI may also benefit patients with subclinical hyperthyroidism, particularly patients at risk of cardiac or systemic complications. The preferred method for treating hyperthyroidism varies in different countries. In a survey of American Thyroid Association (ATA), European Thyroid Association (ETA), and Japanese Thyroid Association (JTA) members, $69 \%, 22 \%$, and $11 \%$ of respondents, respectively, named RAI as the therapy of choice for patients with Grave's disease (Janet and Winfried, 2007). ${ }^{131}$ I has also been used for over 60 years in the treatment of patients with differentiated thyroid cancer. The efficacy of RAI therapy depends on patient preparation, tumour-specific characteristics, the disease site, and the activity of the administered radioiodine (Donald et al., 2003). The predictive value for the 10-year relapse-free survival of one negative ${ }^{131} \mathrm{I}$ thyroid scan is about $90 \%$ after RAI therapy, whereas two consecutive negative scans have a predictive value greater than 95\% (Grigsby et al., 1999).

Another major application of radionuclide therapy is in the treatment of bone metastasis. Over recent decades, several radiopharmaceutical agents have been developed and have shown evidence of safety and efficacy for pain relief in bone metastasis (Fig. 1). The radiopharmaceutical travels selectively to volumes of damaged bone, while sparing normal undamaged bone. Most of the radionuclides used are $\beta^{-}$ emitters, e.g., strontium- $89\left({ }^{89} \mathrm{Sr}\right)$ and samarium- 153 $\left({ }^{153} \mathrm{Sm}\right)$, which release highly energetic electrons that deposit their energy over up to several millimetres 


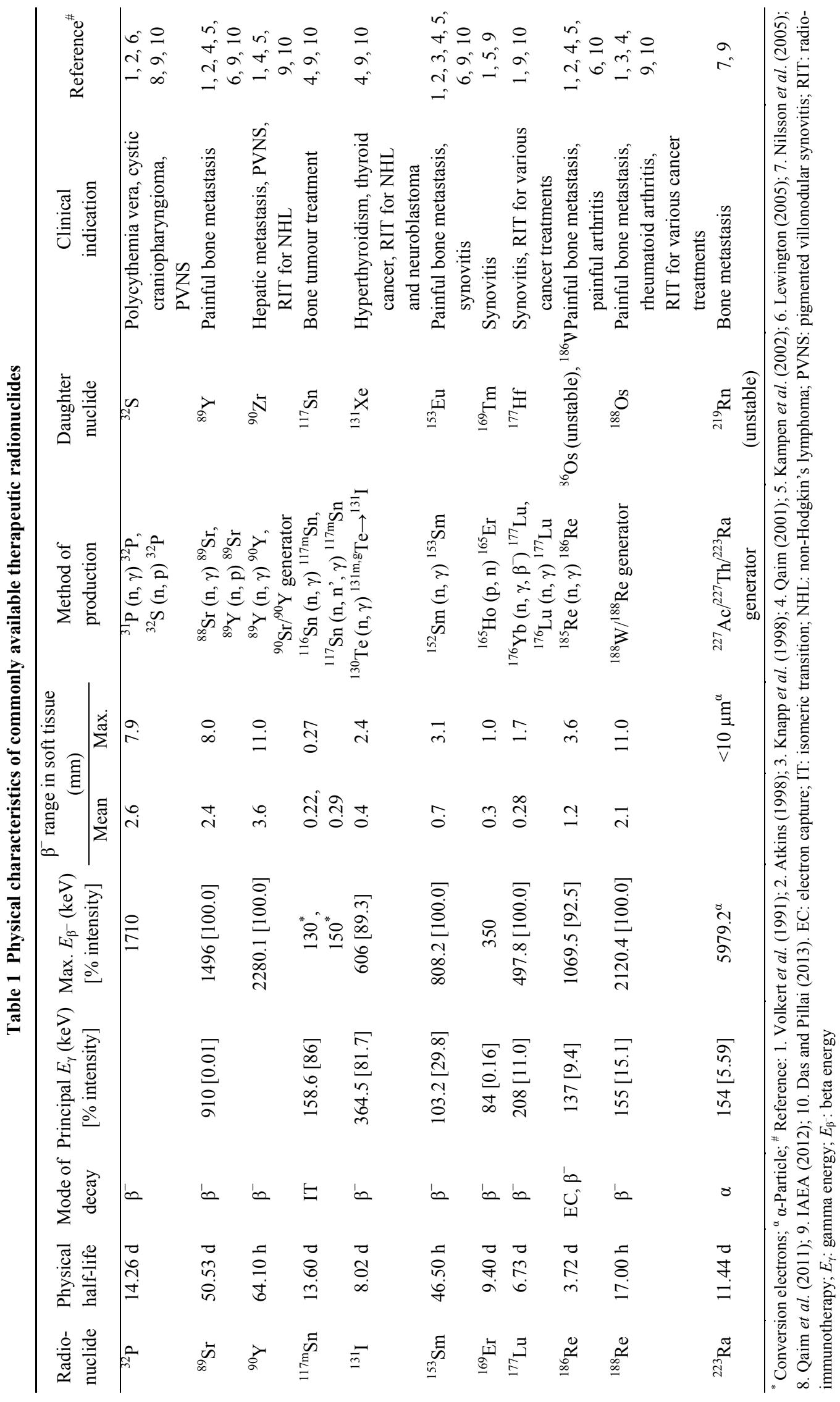




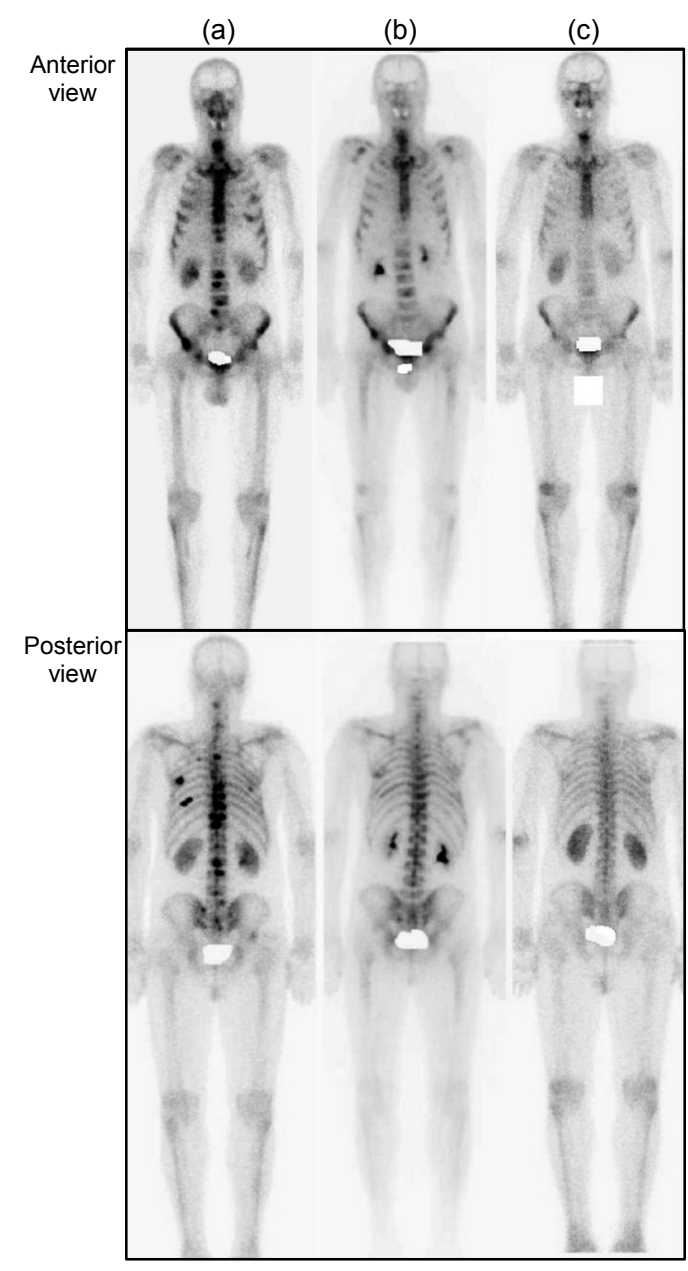

Fig. 1 Serial ${ }^{99 \mathrm{~m}}$ Tc methylenediphosphonate $\left({ }^{99 \mathrm{~m}} \mathrm{Tc}-\right.$ MDP) bone scans in a patient with bone metastasis before (a) and at three (b) and six (c) months after combined treatment of ${ }^{153} \mathrm{Sm}$ oxabifore and denosumab (reprinted with permission from Rasulova et al. (2013)) (a) Multiple osteoblastic bone lesions were observed before the treatment. (b) The lesions showed a decreasing trend at the three-month follow-up scan. (c) Complete resolution of the osteoblastic lesions was seen at the six-month followup scan

in the surrounding tissues. The treatment is effective in reducing pain from bone metastases, with pain relief reported in $60 \%-92 \%$ of patients in several studies (Ackery and Yardley, 1993; Lamb and Faulds, 1997; Pons et al., 1997; Giammarile et al., 2001; Anderson and Nunez, 2007). Tomblyn (2012) has reported that combining ${ }^{89} \mathrm{Sr}$ with chemotherapy appears to improve pain response and may affect survival in patients with metastatic prostate cancer.
Radionuclide therapies are also used for the treatment of a variety of malignancies with ${ }^{131} \mathrm{I},{ }^{90} \mathrm{Y}$, and ${ }^{188} \mathrm{Re}$, polycythemia with ${ }^{32} \mathrm{P}$, chronic joint disease with radiosynovectomy, and intravascular radiation therapy (Werner et al., 1957; Domnitz et al., 1960; Osgood, 1968; Silberstein, 1979; Hoefnagel et al., 1987; Chen et al., 1993; Deutsch et al., 1993; Parmentier and Gardet, 1994; Rhodes et al., 1996; Najean and Rain, 1997a; 1997b; Tavintharan et al., 1997; Chen et al., 2001; Buchmann et al., 2002; Clunie and Fischer, 2003; Chang et al., 2005; Schneider et al., 2005; Das, 2007; Mortazavi et al., 2007; Turkmen et al., 2007; Ugur et al., 2008; Mumtaz et al., 2009; Schultz et al., 2009; Shamim et al., 2010; de la Corte-Rodriguez et al., 2011; Kucuk et al., 2011; Lacin et al., 2011; Liepe et al., 2011; Liepe, 2012). Table 2 summarises the most commonly used radiopharmaceuticals for targeted radionuclide therapy, including their targeting mechanism and clinical indications.

\section{Molecular targeting radionuclide therapy (radioimmunotherapy)}

Radioimmunotherapy (RIT) is a type of cancer cell targeting therapy which uses monoclonal antibodies (mAbs) labelled with a radionuclide directed against tumour-associated antigens. The ability for the antibody to specifically bind to a tumourassociated antigen increases the dose delivered to the tumour cells while decreasing the dose to normal tissues. By nature, the technique requires the tumour cells to express an antigen that is unique to the neoplasm or is inaccessible in normal cells. The appealing concept of RIT was first described by Pressman and Korngold (1953). During the subsequent decades, various RIT radiopharmaceuticals were developed with advances in genetic engineering and chelating techniques. Fig. 2 illustrates the principle of conjugation of a bifunctional chelating agent to an $\mathrm{mAb}$.

Over the decades, an increasing number of new antibodies have been studied in clinical trials and have shown positive evidence of efficacy, particularly in non-Hodgkin's lymphoma (NHL). The current US Food and Drug Administration (FDA)-approved radiopharmaceuticals for RIT include ibritumomabtiuxe$\tan \left(\right.$ Zevalin $^{\circledR}$, approved in 2002) and ${ }^{131}$ I-tositumomab 
Table 2 Commonly used radiopharmaceuticals for targeted radionuclide therapy (Ersahin et al., 2011)

\begin{tabular}{|c|c|c|}
\hline Radiopharmaceutical & Targeting mechanism & Indication \\
\hline${ }^{131}$ I-iodide & Thyroid hormone synthesis & $\begin{array}{l}\text { Differentiated thyroid cancer, Graves' disease, } \\
\text { hyperfunctioning nodules }\end{array}$ \\
\hline${ }^{90} \mathrm{Y}$-microspheres & Intravascular trapping & Liver metastasis, hepatocellular carcinoma \\
\hline${ }^{89}$ Sr-chloride & Calcium analogue & Bone pain palliation \\
\hline${ }^{153}$ Sm-EDTMP & Chemo-adsorption & Bone pain palliation \\
\hline${ }^{90} \mathrm{Y}$-octreotide & Somatostatin receptor binding & Neuroendocrine tumours \\
\hline${ }^{131} \mathrm{I}-\mathrm{MIBG}$ & $\begin{array}{l}\text { Active transport into neuroendocrine } \\
\text { cells and intracellular storage }\end{array}$ & $\begin{array}{l}\text { Neuroblastoma, pheochromacytoma, carcinoid, } \\
\text { paraganglioma, medullary thyroid carcinoma }\end{array}$ \\
\hline
\end{tabular}
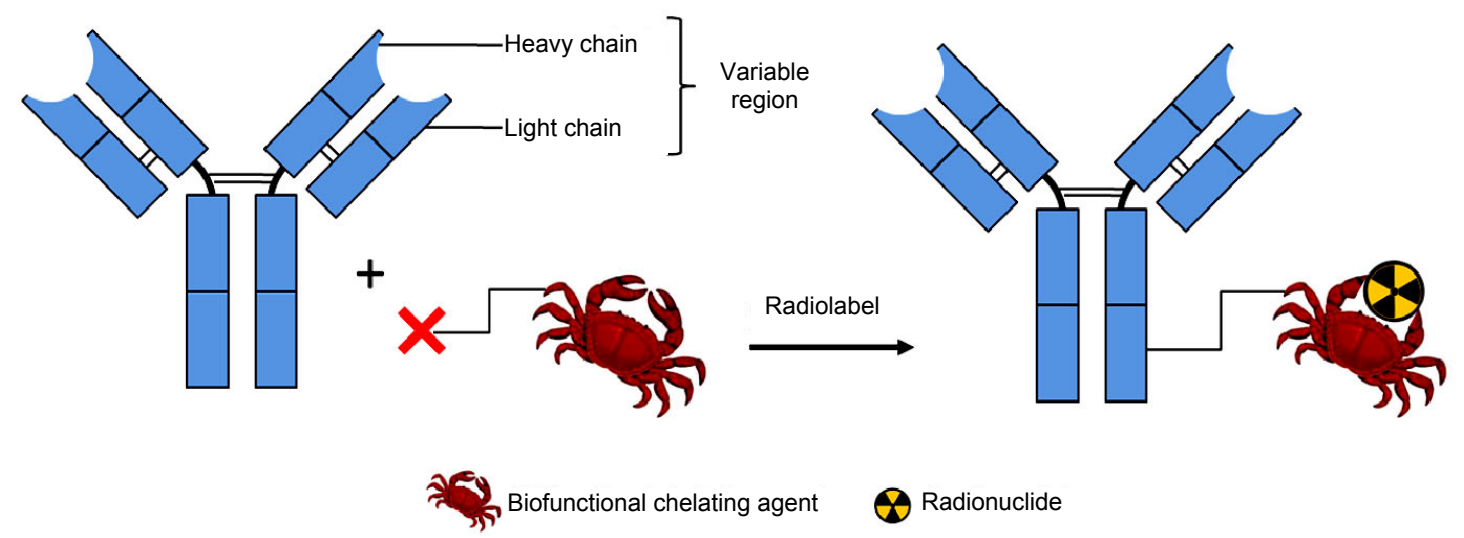

Fig. 2 Graphical illustration of the conjugation of a bifunctional chelating agent to a monoclonal antibody (adapted with permission from Milenic et al. (2004))

The chelating agent has two functionalities: one function is to bind the metallic radionuclides, and the other is to bear the reactive functional group $(\mathrm{X})$ which reacts and covalently binds to $\mathrm{N}$-terminal and $\varepsilon$-amines from lysines on the antibody

regimen $\left(\right.$ Bexxar $^{\circledR}$, approved in 2003), both for the treatment of refractory NHL. Other potential applications of RIT include the treatment of breast, lung, pancreatic, stomach and ovarian carcinoma, neoplastic meningitis, leukemia, high-grade brain glioma, and metastatic colorectal cancer. Table 3 provides a summary of recently developed mAbs in advanced RIT trials and their status (Milenic et al., 2004). The clinical outcomes of these radiopharmaceuticals are discussed in the following section.

\section{$4.1{ }^{90}$ Y-ibritumomab tiuxetan $\left(\right.$ Zevalin $^{\circledR}$ )}

${ }^{90} \mathrm{Y}$-ibritumomab tiuxetan (commonly known as Zevalin $^{\circledR}$ ) is a murine anti-CD20 antibody conjugated to linker-chelator tiuxetan. Zevalin ${ }^{\circledR}$ can be administered as outpatient therapy without significant patient restrictions. In most trials using RIT, patients with diffuse large B-cell lymphoma, follicular lymphoma and mantle cell lymphoma are recruited. In a Phase III trial by Witzig et al. (2002), RIT with Zevalin ${ }^{\circledR}$ was compared with rituximab alone in 143 patients with NHL. The overall response rates (ORRs) were $80 \%$ and $56 \%$, and the complete response rates were $30 \%$ and $16 \%$ in the Zevalin ${ }^{\circledR}$ and rituximab groups, respectively. Alcindor and Witzig (2002) reported an ORR of $74 \%$ in patients with rituximab-refractory NHL treated with Zevalin ${ }^{\circledR}$. Zevalin ${ }^{\circledR}$ was registered for treating relapsed or refractory, low-grade, follicular lymphoma, and transformation B-cell NHL, including refractory NHL following rituximab treatment, and approved by the FDA in 2002. In 2008, Zevalin $^{\circledR}$ was approved for consolidation therapy following partial response or complete response after frontline induction chemotherapy in patients with previously untreated follicular lymphoma in the European Union. 
Table 3 Recently developed monoclonal antibodies (mAbs) for advanced radioimmunotherapy and the status of the clinical trials (adapted from Milenic et al. (2004))

\begin{tabular}{|c|c|c|c|c|c|c|}
\hline Name & $\begin{array}{l}\text { Anti- } \\
\text { body } \\
\text { form }\end{array}$ & $\begin{array}{l}\text { Radio- } \\
\text { nuclide }\end{array}$ & Antigen & Disease & $\begin{array}{l}\text { Clinical trial } \\
\text { status }^{*}\end{array}$ & Manufacturer $^{*}$ \\
\hline $\begin{array}{l}\text { Ibritumomab tiuxetan } \\
\left(\text { Zevalin }^{\circledR}\right)\end{array}$ & muIgG1 & ${ }^{90} \mathrm{Y}$ & CD20 & NHL & $\begin{array}{l}\text { Approved by FDA } \\
\text { in 2002; Phase IV }\end{array}$ & $\begin{array}{l}\text { MDA Nordion, } \\
\text { Canada }\end{array}$ \\
\hline $\begin{array}{l}\text { Tositumomab } \\
\quad\left(\text { Bexxar }^{\mathbb{R}}\right)\end{array}$ & $\begin{array}{c}\text { muIgG2 } \\
\mathrm{a}\end{array}$ & ${ }^{131} \mathrm{I}$ & $\mathrm{CD} 20$ & NHL & $\begin{array}{l}\text { Approved by FDA } \\
\text { in } 2003\end{array}$ & Corixa Corp., USA \\
\hline $\begin{array}{l}\text { Epratuzumab } \\
\quad\left(\text { Lymphocide }^{\circledR}\right)\end{array}$ & $\begin{array}{l}\text { huIgG1 } \\
\text { (LL2) }\end{array}$ & ${ }^{90} \mathrm{Y}$ & $\mathrm{CD} 22$ & $\begin{array}{l}\text { NHL, CLL, immune } \\
\quad \text { diseases }\end{array}$ & Phase III & $\begin{array}{l}\text { Immunomedics } \\
\text { Inc., USA }\end{array}$ \\
\hline $\begin{array}{l}{ }^{131} \text { I-Lym-1 } \\
\quad\left(\text { Oncolym }^{\circledR}\right)\end{array}$ & huIgG1 & ${ }^{131} \mathrm{I}$ & $\begin{array}{l}\text { HLA- } \\
\text { DR10 }\end{array}$ & NHL, CLL & Phase III & $\begin{array}{l}\text { Peregrine Phar- } \\
\text { maceuticals Inc., } \\
\text { USA }\end{array}$ \\
\hline $\begin{array}{l}{ }^{131} \text { I-chTNT-1/B }^{\text {ch }} \\
\left(\text { Cotara }^{\mathbb{B}}\right)\end{array}$ & chIgG1 & ${ }^{131} \mathrm{I}$ & DNA & $\begin{array}{l}\text { Glioblastoma multiforme, } \\
\text { anaplastic astrocytoma }\end{array}$ & Phase III & $\begin{array}{l}\text { Peregrine Phar- } \\
\text { maceuticals Inc., } \\
\text { USA }\end{array}$ \\
\hline $\begin{array}{l}\text { Labetuzumab } \\
\text { (CEA-Cide) }\end{array}$ & huIgG1 & ${ }^{90} \mathrm{Y}$ or & CEA & $\begin{array}{l}\text { Breast, lung, pancreatic, } \\
\text { stomach, and colorectal } \\
\text { carcinoma }\end{array}$ & Pending Phase III & $\begin{array}{l}\text { Immunomedics } \\
\text { Inc., USA }\end{array}$ \\
\hline $\begin{array}{l}\text { Pemtumomab } \\
\left(\text { Theragyn }^{\mathbb{R}}\right)\end{array}$ & muIgG1 & ${ }^{90} \mathrm{Y}$ & PEM & Ovarian, gastric carcinoma & Phase III & Antisoma Plc., UK \\
\hline $\begin{array}{l}{ }^{131} \text { I-metuximab } \\
\left(\operatorname{Licartin}^{\circledR}\right)\end{array}$ & $\begin{array}{l}\text { Hab18 } \\
\text { F(ab')2 }\end{array}$ & ${ }^{131} \mathrm{I}$ & $\begin{array}{l}\text { Hab18G/ } \\
\text { CD147 }\end{array}$ & $\mathrm{HCC}$ & Phase II & $\begin{array}{l}\text { The Fourth Mili- } \\
\text { tary Medical } \\
\text { University, China }\end{array}$ \\
\hline $\begin{array}{l}{ }^{131} \text { I-L19 } \\
\quad\left(\text { Radretumab }^{\circledR}\right)\end{array}$ & L19 & ${ }^{131} \mathrm{I}$ & Fibronectin & $\begin{array}{l}\text { Hepatological malignancy, } \\
\text { refractory Hodgkin's } \\
\text { lymphoma, non-small cell } \\
\text { lung cancer, melanoma, } \\
\text { head and neck carcinoma }\end{array}$ & Phase II & Philogen, Italy \\
\hline $\begin{array}{l}{ }^{90} \mathrm{Y} \text {-clivatuzumab } \\
\text { tetraxetan (PAM4) }\end{array}$ & muIgG1 & ${ }^{90} \mathrm{Y}$ & MUC1 & Pancreatic adenocarcinoma & Phase III & $\begin{array}{l}\text { Immunomedics } \\
\text { Inc., USA }\end{array}$ \\
\hline
\end{tabular}

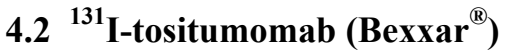

${ }^{131}$ I-Tositumomabor (commonly known as Bexxar $\left.^{\circledR}\right)$ is an mAb that is labelled with ${ }^{131}$ I. Bexxar ${ }^{\circledR}$ is used to treat certain types of NHL. Investigators have been engaged mainly in defining the role of Bexxar ${ }^{\mathbb{B}}$ RIT in treating Hodgkin's lymphoma, diffuse large B-cell lymphoma, and multiple myeloma. Horning et al. (2005) documented that the confirmed ORR was $65 \%$ and the median progression-free survival was 24.5 months for confirmed responders after Bexxar ${ }^{\circledR}$ treatment. In a clinical trial of 60 patients with previously untreated follicular lymphoma, Bexxar $^{\circledR}$ provided a significant therapeutic efficacy compared with that provided by the last qualifying chemotherapy. Based on the promising outcomes, Bexxar $^{\circledR}$ was approved by the FDA for clinical practice in patients with rituximab-relapsed or refractory, low-grade follicular lymphoma in 2003 (Friedberg and Fisher, 2004). One year later, the FDA approved Bexxar $^{\circledR}$ for RIT in NHL patients without previous rituximab therapy (Buchegger et al., 2006).

\subsection{Epratuzumab (Lymphocide ${ }^{\circledR}$ )}

Epratuzumab or Lymphocide ${ }^{\circledR}$ is a ${ }^{90} \mathrm{Y}$ radiolabelled $\mathrm{mAb}$ directed against $\mathrm{CD} 22$ which is an antigen present on the surface of B-cells. Lymphocide ${ }^{\mathbb{R}}$ may be effective against a variety of diseases that involve abnormal B-cells, including NHL and chronic lymphocytic leukemia. It binds to cells that express the CD22 antigen on their surface and kills the cells by high-energy $\beta^{-}$radiation from the ${ }^{90} \mathrm{Y}$. Lymphocide $^{\circledR}$ is currently being tested in Phase III clinical trials in the treatment of lymphoma, leukaemia, and some immune diseases (e.g., lupus). The Phase I/II clinical trial results showed that Lymphocide $^{\circledR}$ has a good safety profile (mostly grade 1 toxicity) and exerts anti-tumour activity in aggressive 
NHL at doses $\geq 240 \mathrm{mg} / \mathrm{m}^{2}$ (Leonard et al., 2004). Ongoing research includes evaluation of epratuzumab in combination with CHOP-rituximab in first line treatment of diffuse large B-cell lymphoma.

\section{$4.4{ }^{131}$ I-Lym-1 (Oncolym $\left.{ }^{\circledR}\right)$}

${ }^{131}$ I-Lym-1 or Oncolym ${ }^{\circledR}$ is an ${ }^{131}$ I-radiolabelled $\mathrm{mAb}$ manufactured by Peregrine Pharmaceuticals Inc., California, USA (formerly known as Techniclone). Oncolym ${ }^{\circledR}$ targets B-cells of NHL patients and is currently in Phase III clinical trials. The radiolabelled antibody will attach to a specific protein, human leukocyte antigen (HLA)-DR10 found only on the surface of B-lymphocytes, such as cancerous B-cells found in many forms of NHL. The HLADR10 protein is usually present on over $80 \%$ of lymphoma cells but only about $2 \%$ of normal blood cells. Therefore, Oncolym ${ }^{\circledR}$ may selectively target lymphoma cancer and spare the healthy B-cells that are required for antibody production. In Phases I and II clinical trials, DeNardo et al. (1998) found that 52\% of patients that had failed conventional chemotherapy achieved partial or complete remission after receiving the treatment with Oncolym ${ }^{\circledR}$. A possible side effect of Oncolym ${ }^{\circledR}$ is reduction of blood cell counts; however, this is usually reversible after the treatment.

\section{$4.5{ }^{131}$ I-chTNT-1/B (Cotara $\left.{ }^{\circledR}\right)$}

${ }^{131} \mathrm{I}$-chTNT-1/B or Cotara ${ }^{\circledR}$ is a genetically engineered chimeric human/mouse $\mathrm{mAb}$ that binds to the DNA-histone H1 complex, a universal nonspecific intracellular antigen found in the necrotic core of solid tumours. These necrotic cells exhibit increased permeability of the cell membrane, and consequently Cotara $^{\circledR}$ can successfully transfer through the cell membrane and karyolemma, target the antigen, and then deliver sufficient energy to destroy adjacent tumour cells. Recently, Cotara ${ }^{\circledR}$ was administered via convection-enhanced delivery to patients in Phase II clinical trials, the majority of whom had anaplastic astrocytoma, brain gliobastoma, hepatocellular carcinoma ( $\mathrm{HCC})$, or colorectal cancer treatment (Lidar et al., 2004; Patel et al., 2005; Vandergrift and Patel, 2006; Ferguson and Lesniak, 2007). In a Phase II clinical trial, 107 patients with lung cancer in eight clinical oncology centres were treated with systemic or intratumoural injections of Cotar ${ }^{\circledR}$. The results demonstrated an ORR of $34.6 \%$, a complete response of $3.7 \%$, a partial response of $30.8 \%$, no change in $55.1 \%$, and progressive disease in $10.3 \%$ of patients (Chen et al., 2005). In 2003, Cotara $^{\circledR}$ was approved for systemic or locoregional treatment of radiotherapy and chemotherapy-refractory or relapse advanced lung cancer by the China Food and Drug Administration (CFDA). A recent Phase II dose confirmation trial with $\operatorname{Cotara}^{\circledR}$ for patients with glioblastoma multiforme at the first relapse has also demonstrated a promising overall survival rate of 41 weeks (Hdeib and Sloan, 2012).

\subsection{Labetuzumab (CEA-Cide)}

Labetuzumab (commonly known as CEA-Cide), is a humanized $\mathrm{mAb}$ labelled with either ${ }^{90} \mathrm{Y}$ or ${ }^{131} \mathrm{I}$ that recognizes carcinoembryonic antigen (AlonsoRuiz et al., 1998). CEA was first described in 1965 by Drs. Gold and Freedman of McGill University (Canada), as a cancer antigen associated with colorectal cancer. It has subsequently served as a serum marker and target for radiolabelled antibody imaging and other therapeutic agents because it is expressed in more than $90 \%$ of colorectal cancer cells. The Phase I/II clinical trials have shown safe and potential use of radiolabelled labetuzumab in the therapy of advanced colorectal and pancreatic cancers. In a Phase II clinical trial, 23 patients underwent Labetuzumab treatment after salvage resection of liver metastasis of colorectal cancer. The median overall survival rate was 68 months, median disease-free survival was 18 months, and five-year survival rate was $51.3 \%$ (Liersch et al., 2005). Both the median overall survival and five-year survival rates were improved compared to historical and contemporaneous controls of not receiving the labetuzumab treatment. The major adverse effect from labetuzumab was transient myelosuppression, resulting mostly in grade $\leq 3$ neutropenia and/or thrombocytopenia.

\subsection{Pemtumomab (Theragyn)}

Pemtumomab (formerly known as Theragyn or HMFG1) is a mouse $\mathrm{mAb}$ conjugated to ${ }^{90} \mathrm{Y}$ that binds specifically to a glycoform of the MUC1 mucin. This protein is overexpressed on the surface of epithelial tumour cells, including ovarian, gastric, breast, and lung cells. From a Phase II study in women with advanced ovarian cancer, 15 out of 21 women who were in remission at the time of treatment with 
pemtumomab responded well and 14 patients were still alive more than eight years after the treatment (Hird et al., 1993). Another feasible use of pemtumomab is in a gastric cancer treatment. One drawback of treatment with murine (mouse) mAbs is that it generates an immunological response in patients, known as the human anti-mouse antibody (HAMA) (Hamacher et al., 2001) response. The common responses include rashes, arthralgia, and myalgia (Maraveyas et al., 1994). It has been suggested that, in addition to any immediate effects of medication by the RIT, murine mAbs may result in a potential longer term benefit from a boost to the immune system provided by the HAMA response (Azinovic et al., 2006). If this hypothesis is correct, then the HAMA response as seen in the patients following pemtumomab treatment is encouraging.

\section{$4.8{ }^{131}$ I-metuximab (Licartin $\left.{ }^{\circledR}\right)$}

${ }^{131}$ I-metuximab or Licartin $^{\circledR}$, developed by the Fourth Military Medical University, China, is a murine $\mathrm{mAb}$ Hab18 $\mathrm{F}(\mathrm{ab}) 2$ fragment against the HCCassociated antigen Hab18G/CD147, with high specificity and affinity for HCC cells. The mAb has a cytotoxic effect and potential ability to inhibit the metastasis of HCC cells by blocking fibroblast cells to produce matrix metalloproteinases. When conjugated to ${ }^{131} \mathrm{I}$, it can afford direct irradiation of tumour cells, and thus enhance the therapeutic efficacy. A multicentre Phase II clinical trial by Chen et al. (2006) showed that the numbers of patients who completed two cycles of Licartin ${ }^{\circledR}$ treatment with a partial response, minor response, or stable disease were 6,14 , and 43 , respectively, and the survival rate at 21 months was $44.5 \%$. Another Chinese multi-centre clinical trial (Wu et al., 2012) showed that the survival rates at 6,12 , and 18 months were $95.6 \%, 80.9 \%$, and $69.1 \%$, respectively, in the group with combination therapy of Licartin ${ }^{\circledR}$ and transcatheter arterial chemoembolization vs. $94.3 \%, 72.9 \%$, and $52.9 \%$, respectively, in the transcatheter arterial chemoembolization (TACE) only group (Tripepi et al., 2011). In addition, the survival rate of stage II patients at one year was significantly higher than that of stage IV patients. Furthermore, the combination therapy of Licartin $^{\circledR}$ and TACE could enhance the efficacy of moderate and advanced HCC patients, especially of patients with post-operation-relapse or multifocal nodular HCC (He et al., 2013). In 2006, Licartin $^{\circledR}$ was approved by the CFDA for treating patients with unresectable or post-operation-relapse $\mathrm{HCC}$, those who were unsuitable for TACE, and those with TACE-refractory or relapse advanced HCC.

\section{$4.9{ }^{131}$ I-L19 (Radretumab ${ }^{\circledR}$ )}

Human mAbs specific to splice isoforms of fibronectin and tenascin-C have been developed, such as L19, F8, F16, and their derivatives (Pini et al., 1998; Brack et al., 2006; Villa et al., 2008). Radretumab $^{\circledR}$, a ${ }^{131}$ I-labelled vascular tumour-targeting antibody in a small immunoprotein L19 format that binds to fibronectin, has been investigated in Phase II clinical trials (Schliemann et al., 2009). Most studies examined the role of Radretumab ${ }^{\circledR}$ in patients with non-small cell lung cancer, some solid tumours (e.g., melanoma and carcinoma of the head and neck), or haematological cancer. Results have been encouraging for the RIT of refractory Hodgkin's lymphoma patients, and more than a hundred patients have been treated with this agent.

\section{$4.10{ }^{90}$ Y-clivatuzumab tetraxetan (PAM4)}

PAM4 is a new mAb known as clivatuzumab. It is highly reactive with pancreatic cancer and precursor lesions but is absent from normal tissues and has limited reactivity with non-pancreatic cancer. These characteristics make it a good agent for pancreatic cancer detection and therapy. In serum analysis, PAM4 has a superior sensitivity and specificity for pancreatic cancer compared to CA19-9. Recent preclinical and clinical trials showed that radiolabeled PAM4 has a great potential to be used as both an immunodiagnostic and an immunotherapeutic agent in the imaging and therapy of pancreatic adenocarcinoma (Han et al., 2014). The ${ }^{90} \mathrm{Y}$-labelled PAM4 is currently undergoing Phase III clinical trials.

\section{Current issues and future prospects of therapeutic radionuclides}

Drug delivery is an important part of targeted radionuclide therapy because merely developing an effective anticancer agent is not sufficient unless it is delivered to the site of action with an adequate dose. Conventional drug development has focused on 
formulations for different routes of administration, mostly oral or injectable, but this is no longer an effective strategy. Nanotechnology, advanced polymer chemistry, and biomedical engineering have contributed to the development of novel methods of drug delivery that target specific tissues without causing too much collateral damage. Innovative methods of cancer treatment, e.g., cell and gene therapies, require innovative drug delivery concepts (Panyam and Labhasetwar, 2003; Ferrari, 2005; Schmaljohann, 2006; Davis et al., 2008; Bertrand et al., 2014).

We will discuss the problems and issues that have yet to be overcome in advanced targeted radionuclide therapy and some possible improvements which can be explored for future development.

\subsection{Supply issues from nuclear reactors}

Various important radionuclides used for diagnostic and therapeutic purposes (e.g. ${ }^{90} \mathrm{Y},{ }^{131} \mathrm{I},{ }^{153} \mathrm{Sm}$, ${ }^{166} \mathrm{Ho},{ }^{177} \mathrm{Lu}$, and ${ }^{188} \mathrm{Re}$ ) are currently produced by nuclear reactors. Although cyclotrons can produce various radionuclides and further research can result in alternative routes for several reactor-produced radionuclides, the roles of nuclear reactors have yet to be completely replaced (Qaim et al., 2011; Krijger et al., 2013). Several main reactors in the world are now aging, which poses a challenge to the constant and reliable supply of medical radionuclides globally (Perkins and Vivian, 2009). To prevent further medical radionuclide shortages, a shared global responsibility is needed by all the stakeholders to replace a small number of aging reactors with modern ones. The replacement projects should be in tandem with up-scaling projects of the most promising alternative radionuclide production routes, preferably under the auspices of an international organisation such as International Atomic Energy Agency (IAEA), to make medical radionuclides less vulnerable to shortages (Muir and Herman, 2001; Perkins et al., 2008; Pillai and Knapp, 2011).

\subsection{New types of radionuclide generators}

Nano-structured materials with nano-scale dimensions have given rise to a new generation of radionuclide generators. With huge surface-to-volume ratios, altered physical properties, tailored surface chemistry, favourable absorption characteristics, and enhanced surface reactivity, nano-structured materi- als are being explored as a new class of absorbent material in column chromatographic separation (Chakravarty and Dash, 2014). They have a potential role to play in the development of a new breed of radionuclide generators for wider applications in both diagnostic and therapeutic nuclear medicine. Nevertheless, development of such generators requires the optimal combination of a suitable nanomaterial and an appropriate parent/daughter radionuclide pair. In addition, the use of nanoparticles as effective adsorbents also requires careful synthesis, structural characterization, detailed adsorption property analysis and a reproducible scaling and manufacturing process to achieve a consistent product with the intended physicochemical characteristics (Chakravarty and Dash, 2014). This new idea is currently under development and has great potential to influence radionuclide generator technology in the future.

\subsection{Contribution of molecular biology}

The performance of cytotoxic drugs is defined by their selectivity of uptake and action in tumour tissue. Due to various peptide receptors being overexpressed on tumour cells, peptide receptor radionuclide therapy has been a promising therapeutic strategy that makes use of high tumour receptor expression to deliver radiation selectively to targeted tumours while sparring the normal tissues (Zaknun et al., 2013). Since radiolabelled peptides display unique characteristics, such as rapid whole-body clearance and tissue penetration, low antigenicity, and convenient production, a series of radiolabelled peptides has been designed for diagnostic and therapeutic applications in oncology (Teunissen et al., 2005; Valkema et al., 2006; Bartolomei et al., 2009; Bodei et al., 2009; Maecke and Reubi, 2011). The radiolabelled peptides have had a great impact in the management of relatively rare neuroendocrine malignancies. For example, ${ }^{111}$ In-pentetreotide $\left({ }^{111} \mathrm{In}\right.$ DTPA-octreotide, where DTPA is the diethylene triamine pentacetate acid), which binds to the somatostatin receptors (SSTRs), has become the gold standard for the diagnosis of neuroendocrine malignancies. Radiolabelled peptide therapy is usually indicated for patients with a widespread disease that is not amenable to targeted radiation therapy or is refractory to chemotherapy (Weiner and Thakur, 2005). Phase I/II studies using various radiolabelled 
peptides, such as ${ }^{111}$ In-pentetreotide, ${ }^{90}$ Y-DOTAPhe $^{1}$-Tyr ${ }^{3}$-octreotide, ${ }^{90}$ Y-DOTA-lanreotide, and ${ }^{177} \mathrm{Lu}$-DOTA-octreotate for the treatment of neuroendocrine malignancies, are still in progress. It is known that ${ }^{90} \mathrm{Y}$-labelled somatostatin analogue (highenergy $\beta^{-}$emitter) is more effective for treating larger tumours and ${ }^{177} \mathrm{Lu}$-labelled somatostatin analogue (low-energy $\beta^{-}$emitter) for treating smaller tumours. de Jong et al. (2002) have suggested a combination of both radionuclides to treat patient with tumours of various sizes with non-homogeneous receptor distribution. Other peptides that are currently under investigation, some of which have shown encouraging results, include ${ }^{188} \mathrm{Re}-\mathrm{P} 2045$ and ${ }^{90} \mathrm{Y}-\alpha_{\mathrm{v}} \beta_{3}$ antagonists (Weiner and Thakur, 2005).

\subsection{Theranostics}

Implementation of the concept of "theranostics" (also known as "theragnostics"), which refers to an integrated approach to diagnosis and therapy using suitable combinations of molecular targeting vectors and radionuclides, has started recently (Alberti, 2012). This can be achieved by using therapeutic radionuclides that also emit radiation for imaging, such as ${ }^{111} \mathrm{In},{ }^{131} \mathrm{I},{ }^{177} \mathrm{Lu}$, and ${ }^{166} \mathrm{Ho}$, for both therapy and diagnostic purposes. Theranostics is usually performed using molecular targeting vectors (e.g., peptides) labelled with either diagnostic or therapeutic radionuclides, targeted specifically by the vector at its molecular level (Baum and Kulkarni, 2012; Srivastava, 2012). One of the classic examples of theranostics is the use of ${ }^{68} \mathrm{Ga}$-labelled tracers, in which the diagnosis using ${ }^{68} \mathrm{Ga}$ can be effectively followed by therapy using therapeutic radionuclides such as ${ }^{90} \mathrm{Y}$ and ${ }^{177} \mathrm{Lu}$ labelled with the same tracer for personalized radionuclide therapy (de Jong et al., 2005) (Fig. 3). The therapeutic radionuclides that are most commonly used or are expected to be widely used in the future are mainly nuclear reactorproduced radionuclides, including ${ }^{47} \mathrm{Sc},{ }^{90} \mathrm{Y},{ }^{131} \mathrm{I}$, ${ }^{166} \mathrm{Ho},{ }^{177} \mathrm{Lu},{ }^{188} \mathrm{Re}$, and ${ }^{213} \mathrm{Bi}$ (IAEA, 2007).
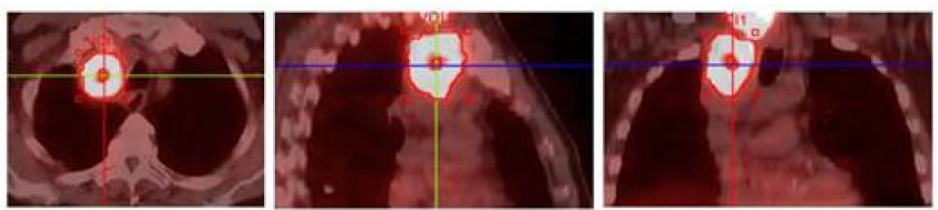

Before PRRNT:

$\mathrm{MTV}=63.5 \mathrm{ml}$

SUV $=8.6$

$\mathrm{MTI}=546.1$
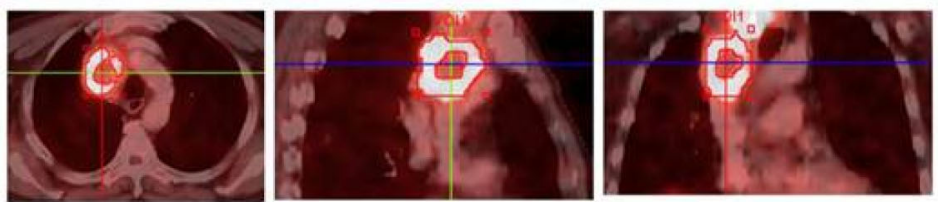

Four months after 1st PRRNT

MTV $=49.4 \mathrm{ml}$

SUV $=7.4$

$\mathrm{MTI}=365.6$
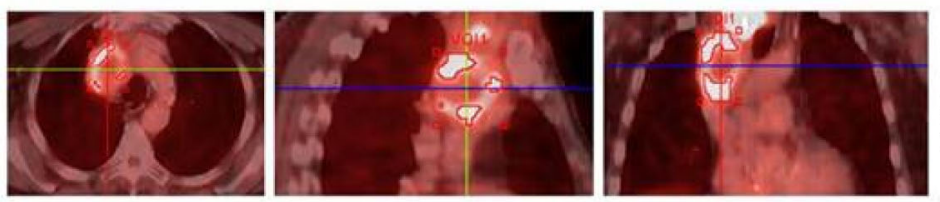

Three months after 2nd PRRNT

$M T V=28.2 \mathrm{ml}$

SUV $=6.3$

$\mathrm{MTI}=177.7$

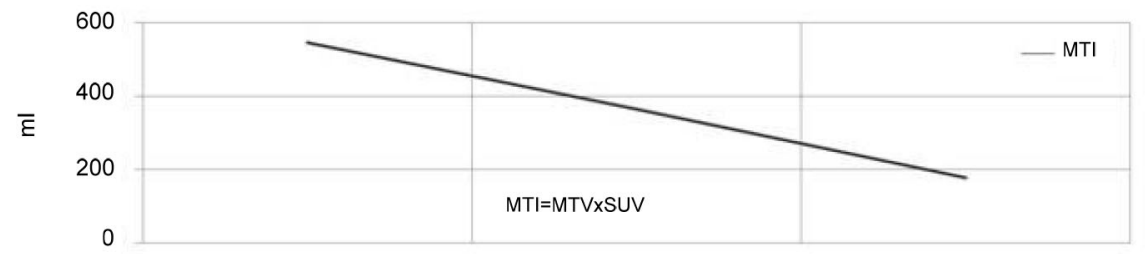

Fig. 3 Example of theranostics application

${ }^{68} \mathrm{Ga}$ somatostatin receptor (SSTR) enables PET/CT imaging to be done for the follow-up and evaluation of molecular response to peptide receptor radionuclide therapy (PRRNT) with ${ }^{177} \mathrm{Lu}-177 /{ }^{90} \mathrm{Y}$-labelled somatostatin analogues. Molecular tumour volume (MTV) can be assessed by quantification of the SSTR density in vivo before and after the PRRNT (reprinted with permission from Baum and Kulkarni (2012)). MTI: molecular tumour index; SUV: standardized uptake value 


\subsection{Contribution of nanotechnology}

Radiolabelled nanoparticles that can be used as platforms for attaching different functionalities for the purposes of multi-modality molecular imaging and multi-valent targeted therapy have been proven to be promising diagnostic and therapeutic tools (El-Sayed et al., 2006; Huang et al., 2006; Gobin et al., 2007). In the last decade, nanotechnology has shown a great potential for the early detection, accurate diagnosis, and personalized treatment of various diseases, especially in cancer therapy (Sahoo et al., 2007). Their size is comparable to biological molecules such as antibodies, and about 100 to 10000 times smaller than human cells. Nanoparticles can interact with the biomolecules both on the surface and inside the cells (Hong et al., 2009). With the capacity of large specific activity inside each particle, nanoparticles can be very useful for internal radiation therapy through passive targeting (i.e., based on the enhanced permeability and retention effect) and/or active targeting (i.e., incorporating a targeting moiety on the nanoparticle) (Mitra et al., 2006). Liposomes, spherical vesicles of lipid bilayers ranging from 100 to $800 \mathrm{~nm}$ diameter, are currently widely used nanoparticles for cancer therapy (Torchilin, 2005).

Other nanoparticles, which have been approved for human use or are currently in clinical trials, include iron oxide, perfluorocarbon, nanotube, quantum dot, micelle, and dendrimer (Fig. 4). The ultimate goal of nanoparticle-based radionuclide therapy is to achieve an efficient and specific in vivo delivery of therapeutic radionuclides without systemic toxicity. It will also facilitate imaging and evaluation of dose delivery and therapeutic efficacy. With the capacity to provide enormous sensitivity and flexibility, nanoparticle-based radionuclide therapy has great potential to improve cancer therapies in the near future (Hong et al., 2009).

\subsection{Image-based dosimetry of radionuclide therapy}

Accurate dosimetric assessment during radionuclide therapy is essential to optimise treatment efficacy for the targeted sites and to minimise radiation exposure to the surrounding normal tissues (Lim, 2013). Individual dosimetry needs to be considered due to various factors contributing to the biological effectiveness in individual patients, including tissue radiosensitivity, dose rate, detailed intraorgan activity distribution, and the cycle therapy scheme (Cremonesi et al., 2006). The organ absorbed dose can be calculated based on biodistribution data derived from Monte Carlo modelling or using more accurate quantitative imaging techniques. The earlier method suggested the use of empirical fixed administered activities, or activities modified by clinical or pathological findings, for general categorized patients. This approach may lead to suboptimal under- or over-dosing as it is not individually tailored (Flux et al., 2006). Recent advances in imaging technology (e.g.,

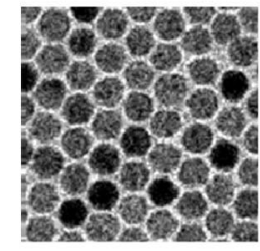

Iron oxide

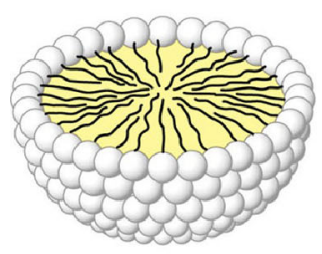

Micelle

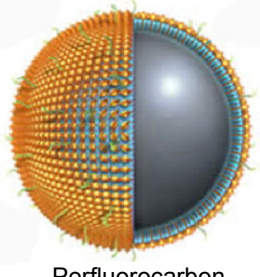

Perfluorocarbon

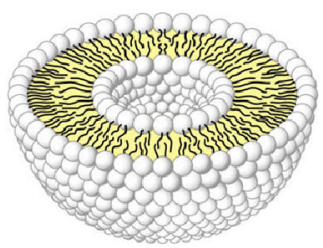

Liposome

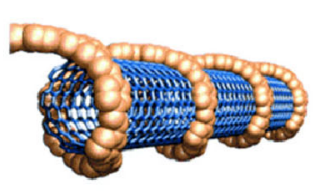

Nanotube

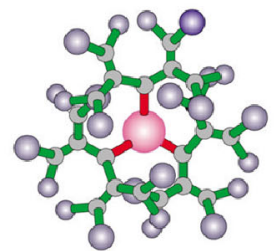

Dendrimer

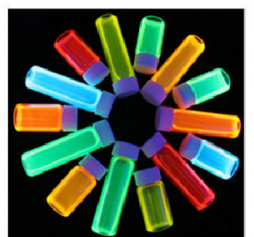

Quantum dot

Fig. 4 Various types of nanoparticles that can be radiolabelled for molecular imaging and targeted radionuclide therapy (reprinted with permission from Hong et al. (2009)) 
quantitative single-photon emission computed tomography (SPECT) and positron emission tomography (PET) image-based dosimetry) allow precise determination of the dose absorbed to the targeted tumours and critical organs for pre-therapeutic treatment planning (individual patient-based). Imagebased dosimetry prior to targeted radionuclide therapy can greatly improve the treatment efficacy and could be applied clinically in the near future.

\subsection{Red marrow dosimetry}

Red marrow toxicity is one of the limiting factors in many radionuclide therapies. Several studies have been carried out to develop models for red marrow dosimetry and tolerance (Stabin et al., 2002). However, red marrow has a very complex structure and the mechanisms regulating uptake activity are still unclear. The radiation burden to the red marrow varies with the radiolabelled molecules, the specific binding, and the residual activity in the blood (Cremonesi et al., 2006). The principal approaches used to evaluate red marrow dose can be categorized as blood- and imaging-based methods. The bloodbased methods were specifically used in the study of radiolabelled mAbs, where there is no specific uptake in the red marrow (Sgouros, 1993). According to Sgouros et al. (1993), the activity concentration in the red marrow was linearly related to the activity concentration in the blood or in the plasma by a factor of 0.2 to 0.4 , likely related to their molecular weight. The implementation of blood-based methods in peptide receptor radionuclide therapy needs an additional parameter, as peptide-bound activity in the red marrow probably distributes in a volume larger than the extracellular space. Forssell-Aronsson et al. (1995) reported a few bone marrow samples taken in patients receiving ${ }^{111}$ In-DTPA-octreotide which showed a red marrow activity concentration equal to that in plasma at the same time points. Consequently, for peptides, a factor for the concentration ratio of red marrow to blood close to one has been suggested (Cremonesi et al., 2006).

Image-based methods apply when images clearly demonstrate a specific uptake in the bone or bone marrow. Using these methods, the activity in selected areas of known red marrow volume (e.g., sacrum and lumbar vertebrae) can be quantified from the images and scaled for the whole red marrow in the patient's body. In most studies with somatostatin analogues, no specific bone marrow localization is detected; hence, the blood activity is used as a surrogate indicator. Images of ${ }^{111} \mathrm{In}$ - or ${ }^{177} \mathrm{Lu}$-labelled somatostatin analogues usually do not show any significant uptake in red marrow or in bone. Consequently, many authors prefer to extrapolate the red marrow dose from the time-activity curve in the blood, plasma, or remaining tissues (Cremonesi et al., 1999; Forster et al., 2001). The assessment of bone marrow dose still remains a challenge in most of the targeted radionuclide therapies.

\subsection{RIT vs. non-radiolabelled immunotherapy}

Recent advances in cancer immunotherapy, i.e., immune-checkpoint antibody blockade, adoptive T-cell therapy, anti-CD47 antibodies, and anti-GD2 antibodies, have shown a significant efficacy in the treatment of late-stage solid tumours and have become a breakthrough for cancer therapy. The antitumour efficacy of many therapeutic antibodies can be enhanced by their use in combination with RIT. The advantages of RIT include short treatment time and reduced side-effects. The radioactivity decays slowly, so that it is able to continue irradiating the cells over a period of time after the delivery of a single dose. Although the radiation may also kill healthy cells, the damage will be confined mostly to the adjacent targeted area. Some patients may experience nausea and vomiting, but to a lesser degree than with chemotherapy.

An earlier study performed by Witzig et al. (2002) comparing the treatment efficacy of RIT with ${ }^{90}$ Y-ibritumomab tiuxetan $\left(\right.$ Zevalin $\left.^{\circledR}\right)$ with a control immunotherapy, rituximab in 143 patients with relapsed or refractory low-grade, follicular, or transformed B-cell NHL, has shown that the ORR for the RIT group ( $n=73$ ) was $80 \%$, vs. $56 \%$ for the ritiuximab group $(n=70)(P=0.002)$, whereas the complete response (CR) rates were $30 \%$ and $16 \%$ in the RIT and rituximab groups, respectively $(P=0.04)$. The study concluded that RIT with ${ }^{90} \mathrm{Y}$-ibritumomab tiuxetan was well tolerated and produced statistically and clinically significantly higher ORRs and CRs compared with rituximab alone. Similar studies should be carried out in the future to explore the potential benefits of a combination therapy of radionuclide with cancer immunotherapy. 


\section{Conclusions}

Therapeutic nuclear medicine is developing rapidly as an alternative choice of treatment in oncology. Other than its traditional uses in endocrinology and rheumatology, therapeutic radionuclides have now gained attention for tumour targeting therapy using multiple routes and mechanisms to target radionuclides in the tumour site. The non-invasiveness of the procedure and relatively low toxicity in comparison to conventional chemotherapy and external beam radiotherapy make radionuclide therapy an attractive and realistic alternative in the management of benign and malignant diseases. Although there are still many challenges, such as a low target-to-non-target rate, poorer therapeutic efficacy in solid tumours compared to haematological tumours, and a lack of radionuclide generators, we believe that, with advances in administration methods, a combination of multiple treatment modalities and enhanced therapeutic efficacy, the contribution of therapeutic radionuclides to tumour treatment will significantly increase in the future.

\section{Acknowledgements}

The authors would like to acknowledge the following contributors of the images in this publication: Nigora RASULOVA, Vladimir LYUBSHIN, Dauranbek ARYBZHANOV, Valery KRYLOV, Marat KHODJIBEKOV, Diane E. MILENIC, Erik D. BRADY, Martin W. BRECHBIEL, Richard P. BAUM, Harshad R. KULKARNI, Hao HONG, Yin ZHANG, Jiang-tao SUN, and Wei-bo CAI.

\section{Compliance with ethics guidelines}

Chai-Hong YEONG, Mu-hua CHENG, and Kwan-Hoong NG declare that they have no conflict of interest.

This article does not contain any studies with human or animal subjects performed by any of the authors.

\section{References}

Ackery, D., Yardley, J., 1993. Radionuclide-targeted therapy for the management of metastatic bone pain. Semin. Oncol., 20(3 Suppl. 2):27-31.

Alberti, C., 2012. From molecular imaging in preclinical/ clinical oncology to theranostic applications in targeted tumor therapy. Eur. Rev. Med. Pharmacol. Sci., 16(14): 1925-1933.

Alcindor, T., Witzig, T.E., 2002. Radioimmunotherapy with yttrium-90 ibritumomab tiuxetan for patients with relapsed CD20 ${ }^{+}$B-cell non-Hodgkin's lymphoma. Curr. Treat. Options Oncol., 3(4):275-282. [doi:10.1007/ s11864-002-0027-y]
Alonso-Ruiz, A., Perez-Ruiz, F., Calabozo, M., et al., 1998. Efficacy of radiosynovectomy of the knee in rheumatoid arthritis: evaluation with magnetic resonance imaging. Clin. Rheumatol., 17(4):277-281. [doi:10.1007/BF01451005]

Anderson, P., Nunez, R., 2007. Samarium lexidronam $\left({ }^{153} \mathrm{Sm}-\right.$ EDTMP): skeletal radiation for osteoblastic bone metastases and osteosarcoma. Expert Rev. Anticancer Ther., 7(11):1517-1527. [doi:10.1586/14737140.7.11.1517]

Arslan, N., Emi, M., Alagoz, E., et al., 2011. Selective intraarterial radionuclide therapy with Yttrium-90 (Y-90) microspheres for hepatic neuroendocrine metastases: initial experience at a single center. Vojnosanit. Pregl., 68(4):341-348. [doi:10.2298/VSP1104341A]

Atkins, H.L., 1998. Overview of nuclides for bone pain palliation. Appl. Radiat. Isot., 49(4):277-283. [doi:10. 1016/S0969-8043(97)00039-0]

Azinovic, I., DeNardo, G.L., Lamborn, K.R., et al., 2006. Survival benefit associated with human anti-mouse antibody (HAMA) in patients with B-cell malignancies. Cancer Immunol. Immunother., 55(12):1451-1458. [doi: 10.1007/s00262-006-0148-4]

Bartolomei, M., Bodei, L., de Cicco, C., et al., 2009. Peptide receptor radionuclide therapy with ${ }^{90} \mathrm{Y}$-DOTATOC in recurrent meningioma. Eur. J. Nucl. Med. Mol. Imaging, 36(9):1407-1416. [doi:10.1007/s00259-009-1115-z]

Baum, R.P., Kulkarni, H.R., 2012. THERANOSTICS: from molecular imaging using Ga-68 labeled tracers and $\mathrm{PET} / \mathrm{CT}$ to personalized radionuclide therapy - the bad Berka experience. Theranostics, 2(5):437-447. [doi:10. 7150/thno.3645]

Bertrand, N., Wu, J., Xu, X., et al., 2014. Cancer nanotechnology: the impact of passive and active targeting in the era of modern cancer biology. Adv. Drug Deliv. Rev., 66:2-25. [doi:10.1016/j.addr.2013.11.009]

Bodei, L., Ferone, D., Grana, C.M., et al., 2009. Peptide receptor therapies in neuroendocrine tumors. J. Endocrinol. Invest., 32(4):360-369. [doi:10.1007/BF03345728]

Brack, S.S., Silacci, M., Birchler, M., et al., 2006. Tumortargeting properties of novel antibodies specific to the large isoform of tenascin-C. Clin. Cancer Res., 12(10): 3200-3208. [doi:10.1158/1078-0432.CCR-05-2804]

Buchegger, F., Antonescu, C., Delaloye, A.B., et al., 2006. Long-term complete responses after ${ }^{131}$ I-tositumomab therapy for relapsed or refractory indolent non-Hodgkin's lymphoma. Br. J. Cancer, 94(12):1770-1776. [doi:10. 1038/sj.bjc.6603166]

Buchmann, I., Bunjes, D., Kotzerke, J., et al., 2002. Myeloablative radioimmunotherapy with Re-188-antiCD66-antibody for conditioning of high-risk leukemia patients prior to stem cell transplantation: biodistribution, biokinetics and immediate toxicities. Cancer Biother. Radiopharm., 17(2):151-163. [doi:10.1089/10849780 2753773775]

Carrasquillo, J.A., Pandit-Taskar, N., Chen, C.C., 2012. Radionuclide therapy of adrenal tumors. J. Surg. Oncol., 106(5):632-642. [doi:10.1002/jso.23196]

Chakravarty, R., Dash, A., 2014. Nanomaterial-based 
adsorbents: the prospect of developing new generation radionuclide generators to meet future research and clinical demands. J. Radioanal. Nucl. Chem., 299(1):741-757. [doi:10.1007/s10967-013-2823-1]

Chang, C.H., Tsai, L.C., Chen, S.T., et al., 2005. Radioimmunotherapy and apoptotic induction on CK19overexpressing human cervical carcinoma cells with Re188-mAbCx-99. Anticancer Res., 25(4):2719-2728.

Chen, F.D., Hsieh, B.T., Wang, H.E., et al., 2001. Efficacy of Re-188-labelled sulphur colloid on prolongation of survival time in melanoma-bearing animals. Nucl. Med. Biol., 28(7):835-844. [doi:10.1016/S0969-8051(01)00244-X]

Chen, S., Yu, L., Jiang, C., et al., 2005. Pivotal study of iodine-131-labeled chimeric tumor necrosis treatment radioimmunotherapy in patients with advanced lung cancer. J. Clin. Oncol., 23(7):1538-1547. [doi:10.1200/ JCO.2005.06.108]

Chen, W.L., Guan, S.I., Huang, W.S., 1993. Radioiodine I-131 therapy in the management of differentiated thyroid carcinoma: a review of 202 patients. J. Formos. Med. Assoc., 92(7):623-631. [doi:10.1016/j.ijrobp.2005.12.034]

Chen, Z.N., Mi, L., Xu, J., et al., 2006. Targeting radioimmunotherapy of hepatocellular carcinoma with iodine $\left.{ }^{(131} \mathrm{I}\right)$ metuximab injection: clinical Phase I/II trials. Int. $J$. Radiat. Oncol. Biol. Phys., 65(2):435-444. [doi:10.1016/j. ijrobp.2005.12.034]

Chiacchio, S., Mazzarri, S., Lorenzoni, A., et al., 2011. Radionuclide therapy and integrated protocols for bone metastases. Q. J. Nucl. Med. Mol. Imaging, 55(4):431-447.

Clunie, G., Fischer, M., 2003. EANM procedure guidelines for radiosynovectomy. Eur. J. Nucl. Med. Mol. Imaging, 30(3):B12-B16. [doi:10.1007/s00259-002-1058-0]

Cremonesi, M., Ferrari, M., Zoboli, S., et al., 1999. Biokinetics and dosimetry in patients administered with ${ }^{111}$ In-DOTA$\mathrm{Tyr}^{3}$-octreotide: implications for internal radiotherapy with ${ }^{90}$ Y-DOTATOC. Eur. J. Nucl. Med. Mol. Imaging, 26(8):877-886. [doi:10.1007/s002590050462]

Cremonesi, M., Ferrari, M., Bodei, L., et al., 2006. Dosimetry in peptide radionuclide receptor therapy: a review. J. Nucl. Med., 47(9):1467-1475.

Das, B.K., 2007. Role of radiosynovectomy in the treatment of rheumatoid arthritis and hemophilic arthropathies. Biomed. Imaging Interv. J., 3(4):e45. [doi:10.2349/biij.3. 4.e45]

Das, T., Pillai, M.R., 2013. Options to meet the future global demand of radionuclides for radionuclide therapy. $\mathrm{Nucl}$. Med. Biol., 40(1):23-32. [doi:10.1016/j.nucmedbio. 2012. 09.007]

Dash, A., Knapp, F.F., Pillai, M.R., 2013. Targeted radionuclide therapy - an overview. Curr. Radiopharm., 6(3): 152-180. [doi:10.2174/18744710113066660023]

Davis, M.E., Chen, Z.G., Shin, D.M., 2008. Nanoparticle therapeutics: an emerging treatment modality for cancer. Nat. Rev. Drug Discov., 7(9):771-782. [doi:10.1038/ $\operatorname{nrd} 2614]$

de Jong, M., Valkema, R., Jamar, F., et al., 2002. Somatostatin receptor-targeted radionuclide therapy of tumors: pre- clinical and clinical findings. Semin. Nucl. Med., 32(2): 133-140. [doi:10.1053/snuc.2002.31027]

de Jong, M., Breeman, W.A., Valkema, R., et al., 2005. Combination radionuclide therapy using ${ }^{177} \mathrm{Lu}$ - and ${ }^{90}$ Y-labeled somatostatin analogs. J. Nucl. Med., 46(S1):13S-17S.

de la Corte-Rodriguez, H., Rodriguez-Merchan, E.C., JimenezYuste, V., 2011. Radiosynovectomy in hemophilia: quantification of its effectiveness through the assessment of 10 articular parameters. J. Thromb. Haemost., 9(5): 928-935. [doi:10.1111/j.1538-7836.2011.04246.x]

DeNardo, G.L., DeNardo, S.J., Lamborn, K.R., et al., 1998. Low-dose, fractionated radioimmunotherapy for B-cell malignancies using ${ }^{131} \mathrm{I}$-Lym-1 antibody. Cancer Biother. Radiopharm., 13(4):239-254. [doi:10.1089/cbr.1998. 13.239]

Deutsch, E., Brodack, J.W., Deutsch, K.F., 1993. Radiation synovectomy revisited. Eur. J. Nucl. Med., 20(11): 1113-1127. [doi:10.1007/BF00173494]

Domnitz, J., Hurd, H.F., Goldzieher, J.W., 1960. The evaluation of I-131 therapy of Graves' disease. Reliability and prognostic value of chemical and radioactive iodine studies. Arch. Intern. Med., 106(2):194-204. [doi:10. 1001/archinte.1960.03820020034006]

Donald, W.K., Raphael, E.P., Ralph, R.W., et al., 2003. Holland-Frei Cancer Medicine. Hamilton, BC Decker.

El-Sayed, I.H., Huang, X., El-Sayed, M.A., 2006. Selective laser photo-thermal therapy of epithelial carcinoma using anti-EGFR antibody conjugated gold nanoparticles. Cancer Lett., 239(1):129-135. [doi:10.1016/j.canlet.2005. 07.035]

Ersahin, D., Doddamane, I., Cheng, D., 2011. Targeted radionuclide therapy. Cancers, 3(4):3838-3855. [doi:10. 3390/cancers3043838]

Ezziddin, S., Meyer, C., Kahancova, S., et al., 2012. ${ }^{90} \mathrm{Y}$ radioembolization after radiation exposure from peptide receptor radionuclide therapy. J. Nucl. Med., 53(11): 1663-1669. [doi:10.2967/jnumed.112.107482]

Ferguson, S., Lesniak, M.S., 2007. Convection enhanced drug delivery of novel therapeutic agents to malignant brain tumors. Curr. Drug Deliv., 4(2):169-180. [doi:10.2174/ 156720107780362302]

Ferrari, M., 2005. Cancer nanotechnology: opportunities and challenges. Nat. Rev. Cancer, 5(3):161-171. [doi:10. 1038/nrc1566]

Flux, G., Bardies, M., Monsieurs, M., et al., 2006. The impact of PET and SPECT on dosimetry for targeted radionuclide therapy. Z. Med. Phys., 16(1):47-59.

Forrer, F., Waldherr, C., Maecke, H.R., et al., 2006. Targeted radionuclide therapy with ${ }^{90} \mathrm{Y}$-DOTATOC in patients with neuroendocrine tumors. Anticancer Res., 26(1B): 703-707.

Forssell-Aronsson, E., Fjalling, M., Nilsson, O., et al., 1995. Indium-111 activity concentration in tissue samples after intravenous injection of indium-111-DTPA-D-Phe-1octreotide. J. Nucl. Med., 36(1):7-12.

Forster, G.J., Engelbach, M.J., Brockmann, J.J., et al., 2001. 
Preliminary data on biodistribution and dosimetry for therapy planning of somatostatin receptor positive tumours: comparison of ${ }^{86}$ Y-DOTATOC and ${ }^{111} \mathrm{In}$ DTPA-octreotide. Eur. J. Nucl. Med., 28(12):1743-1750. [doi:10.1007/s002590100628]

Friedberg, J.W., Fisher, R.I., 2004. Iodine-131 tositumomab (Bexxar): radioimmunoconjugate therapy for indolent and transformed B-cell non-Hodgkin's lymphoma. Expert Rev. Anticancer Ther., 4(1):18-26. [doi:10.1586/ 14737140.4.1.18]

Gabriel, M., 2012. Radionuclide therapy beyond radioiodine. Wien Med. Wochenschr., 162(19-20):430-439. [doi:10. 1007/s10354-012-0128-6]

Giammarile, F., Mognetti, T., Resche, I., 2001. Bone pain palliation with strontium- 89 in cancer patients with bone metastases. Q. J. Nucl. Med., 45(1):78-83.

Gobin, A.M., Lee, M.H., Halas, N.J., et al., 2007. Nearinfrared resonant nanoshells for combined optical imaging and photothermal cancer therapy. Nano Lett., 7(7):1929-1934. [doi:10.1021/n1070610y]

Grigsby, P.W., Baglan, K., Siegel, B.A., 1999. Surveillance of patients to detect recurrent thyroid carcinoma. Cancer, 85(4):945-951. [doi:10.1002/(SICI)1097-0142(19990215) 85:4<945::AID-CNCR24>3.0.CO;2-I]

Gulenchyn, K.Y., Yao, X., Asa, S.L., et al., 2012. Radionuclide therapy in neuroendocrine tumours: a systematic review. Clin. Oncol., 24(4):294-308. [doi:10.1016/j.clon. 2011.12.003]

Hamacher, K.A., Den, R.B., Den, E.I., et al., 2001. Cellular dose conversion factors for $\alpha$-particle-emitting radionuclides of interest in radionuclide therapy. J. Nucl. Med., 42(8):1216-1221.

Han, S., Jin, G., Wang, L., et al., 2014. The role of PAM4 in the management of pancreatic cancer: diagnosis, radioimmunodetection, and radioimmunotherapy. J. Immunol. Res., 2014:268479. [doi:10.1155/2014/268479]

Hdeib, A., Sloan, A., 2012. Targeted radioimmunotherapy: the role of ${ }^{131}$ I-chTNT-1/B mAb (Cotara) for treatment of high-grade gliomas. Future Oncol., 8(6):659-669. [doi:10.2217/fon.12.58]

He, Q., Lu, W.S., Liu, Y., et al., 2013. ${ }^{131}$ I-labeled metuximab combined with chemoembolization for unresectable hepatocellular carcinoma. World J. Gastroenterol., 19(47) 9104-9110. [doi:10.3748/wjg.v19.i47.9104]

Hird, V., Maraveyas, A., Snook, D., et al., 1993. Adjuvant therapy of ovarian cancer with radioactive monoclonal antibody. Br. J. Cancer, 68(2):403-406. [doi:10.1038/bjc. 1993.349]

Hoefnagel, C.A., 1991. Radionuclide therapy revisited. Eur. J. Nucl. Med., 18(6):408-431. [doi:10.1007/BF02258432]

Hoefnagel, C.A., 1998. Radionuclide cancer therapy. Ann. Nucl. Med., 12(2):61-70. [doi:10.1007/BF03164831]

Hoefnagel, C.A., den Hartog Jager, F.C., Taal, B.G., et al., 1987. The role of I-131-MIBG in the diagnosis and therapy of carcinoids. Eur. J. Nucl. Med., 13(4):187-191. [doi:10.1007/BF00256489]

Hong, H., Zhang, Y., Sun, J., et al., 2009. Molecular imaging and therapy of cancer with radiolabeled nanoparticles. Nanotoday, 4(5):399-413. [doi:10.1016/j.nantod.2009. 07.001]

Horning, S.J., Younes, A., Jain, V., et al., 2005. Efficacy and safety of tositumomab and iodine-131 tositumomab (Bexxar) in B-cell lymphoma, progressive after rituximab. J. Clin. Oncol., 23(4):712-719. [doi:10.1200/JCO.2005. 07.040]

Houle, S., Yip, T.K., Shepherd, F.A., et al., 1989. Hepatocellular carcinoma: pilot trial of treatment with Y-90 microspheres. Radiology, 172(3):857-860. [doi:10.1148/ radiology.172.3.2549567]

Huang, X., El-Sayed, I.H., Qian, W., et al., 2006. Cancer cell imaging and photothermal therapy in the near-infrared region by using gold nanorods. J. Am. Chem. Soc., 128(6):2115-2120. [doi:10.1021/ja057254a]

International Atomic Energy Agency (IAEA), 2007. Trends in radiopharmaceuticals (ISTR-2005). Proceedings of an International Symposium Organized by the IAEA, Vienna, Austria.

International Atomic Energy Agency (IAEA), 2012. Nuclear data for production of therapeutic radionuclides. Technical Report Series 473. IAEA, Vienna, Austria.

Janet, F.E., Winfried, B., 2007. Nuclear Medicine Therapy. Informa Healthcare USA, New York.

Kampen, W.U., Brenner, W., Czech, N., et al., 2002. Intraarticular application of unsealed $\beta$-emitting radionuclides in the treatment course of inflammatory joint diseases. Curr. Med. Chem. Anti-Inflamm. Anti-Allergy Agents, 1(1): 77-87. [doi:10.2174/156801402460 6502]

Kassis, A.I., Adelstein, S.J., 2005. Radiobiologic principles in radionuclide therapy. J. Nucl. Med., 46(S1):4S-12S.

Knapp, F.F.R.Jr., Mirzadeh, S., Beets, A.L., et al., 1998. Reactor-produced radioisotopes from ORNL for bone pain palliation. Appl. Radiat. Isot., 49(4):309-315. [doi:10. 1016/S0969-8043(97)00043-2]

Krijger, G.C., Ponsard, B., Harfensteller, M., et al., 2013. The necessity of nuclear reactors for targeted radionuclide therapies. Trends Biotechnol., 31(7):390-396. [doi:10. 1016/j.tibtech.2013.04.007]

Kucuk, O.N., Soydal, C., Lacin, S., et al., 2011. Selective intraarterial radionuclide therapy with yttrium-90 (Y-90) microspheres for unresectable primary and metastatic liver tumors. World J. Surg. Oncol., 9(1):86. [doi:10. 1186/1477-7819-9-86]

Lacin, S., Kucuk, O., Oz, I., et al., 2011. Selective intra-arterial Y-90 microsphere therapy in hemangioendothelioma. Turk. J. Gastroenterol., 22(1):89-92.

Lamb, H.M., Faulds, D., 1997. Samarium ${ }^{153}$ Sm lexidronam. Drugs Aging, 11(5):413-418. [doi:10.2165/00002512199711050-00007]

Lambert, B., van Vlierberghe, H., Troisi, R., et al., 2010. Radionuclide therapy for hepatocellular carcinoma. Acta Gastroenterol. Belg., 73(4):484-488.

Leonard, J.P., Coleman, M., Ketas, J.C., et al., 2004. Epratuzumab, a humanized anti-CD22 antibody, in aggressive non-Hodgkin's lymphoma: Phase I/II clinical 
trial results. Clin. Cancer Res., 10(16):5327-5334. [doi: 10.1158/1078-0432.CCR-04-0294]

Lewington, V.J., 2005. Bone-seeking radionuclides for therapy. J. Nucl. Med., 46(S1):38S-47S.

Lidar, Z., Mardor, Y., Jonas, T., et al., 2004. Convectionenhanced delivery of paclitaxel for the treatment of recurrent malignant glioma: a Phase I/II clinical study. $J$. Neurosurg., 100(3):472-479. [doi:10.3171/jns.2004.100. 3.0472]

Liepe, K., 2012. Efficacy of radiosynovectomy in rheumatoid arthritis. Rheumatol. Int., 32(10):3219-3224. [doi:10. 1007/s00296-011-2143-0]

Liepe, K., Zaknun, J.J., Padhy, A., et al., 2011. Radiosynovectomy using yttrium-90, phosphorus-32 or rhenium188 radiocolloids versus corticoid instillation for rheumatoid arthritis of the knee. Ann. Nucl. Med., 25(5): 317-323. [doi:10.1007/s12149-011-0467-1]

Liersch, T., Meller, J., Kulle, B., et al., 2005. Phase II trial of carcinoembryonic antigen radioimmunotherapy with ${ }^{131}$ I-labetuzumab after salvage resection of colorectal metastases in the liver: five-year safety and efficacy results. J. Clin. Oncol., 23(27):6763-6770. [doi:10.1200/ JCO.2005.18.622]

Lim, I., 2013. Image-based dosimetry of radionuclide therapy. J. Korean Thyroid Assoc., 6(1):26-33. [doi:10.11106/jkta. 2013.6.1.26]

MacKee, G.M., 1921. X-rays and Radium in the Treatment of Diseases of the Skin. Lea \& Febiger, New York.

Maecke, H.R., Reubi, J.C., 2011. Somatostatin receptors as targets for nuclear medicine imaging and radionuclide treatment. J. Nucl. Med., 52(6):841-844. [doi:10.2967/ jnumed.110.084236]

Maraveyas, A., Snook, D., Hird, V., et al., 1994. Pharmacokinetics and toxicity of an yttrium-90-CITC-DTPAHMFG1 radioimmunoconjugate for intraperitoneal radioimmunotherapy of ovarian cancer. Cancer, 73(S3): 1067-1075. [doi:10.1002/1097-0142(19940201)73:3+< 1067::AID-CNCR2820731346>3.0.CO;2-\#]

Milenic, D.E., Brady, E.D., Brechbiel, M.W., 2004. Antibodytargeted radiation cancer therapy. Nat. Rev. Drug Discov., 3(6):488-499. [doi:10.1038/nrd1413]

Mitra, A., Nan, A., Line, B.R., et al., 2006. Nanocarriers for nuclear imaging and radiotherapy of cancer. Curr. Pharm. Des., 12(36):4729-4749. [doi:10.2174/1381612067790 26317]

Mortazavi, S.M., Asadollahi, S., Farzan, M., et al., 2007. ${ }^{32} \mathrm{P}$ colloid radiosynovectomy in treatment of chronic haemophilic synovitis: Iran experience. Haemophilia, 13(2): 182-188. [doi:10.1111/j.1365-2516.2006.01424.x]

Muir, D.W., Herman, M., 2001. Long term needs for nuclear data development: summary report of the advisory group meeting. International Atomic Energy Agency, Vienna, Austria.

Mumtaz, M., Lin, L.S., Hui, K.C., et al., 2009. Radioiodine I-131 for the therapy of Graves' disease. Malays. J. Med. Sci., 16(1):25-33.

Najean, Y., Rain, J.D., 1997a. Treatment of polycythemia vera: use of ${ }^{32} \mathrm{P}$ alone or in combination with maintenance therapy using hydroxyurea in 461 patients greater than 65 years of age. Blood, 89(7):2319-2327.

Najean, Y., Rain, J.D., 1997b. The very long-term evolution of polycythemia vera: an analysis of 318 patients initially treated by phlebotomy or ${ }^{32} \mathrm{P}$ between 1969 and 1981 . Seminars Hematol., 34(1):6-16.

Nakabeppu, Y., Nakajo, M., 1994. Radionuclide therapy of malignant pheochromocytoma with ${ }^{131}$ I-MIBG. Ann. Nucl. Med., 8(4):259-268. [doi:10.1007/BF03165029]

Nestor, M.V., 2010. Targeted radionuclide therapy in head and neck cancer. Head Neck, 32(5):666-678. [doi:10.1002/ hed.21243]

Nilsson, S., Larsen, R.H., Fossa, S.D., et al., 2005. First clinical experience with $\alpha$-emitting radium-223 in the treatment of skeletal metastases. Clin. Cancer Res., 11(12):4451-4459. [doi:10.1158/1078-0432.CCR-04-2244]

Osgood, E.E., 1968. The case for ${ }^{32} \mathrm{P}$ in treatment of polycythemia vera. Blood, 32(3):492-499.

Panyam, J., Labhasetwar, V., 2003. Biodegradable nanoparticles for drug and gene delivery to cells and tissue. $A d v$. Drug Deliv. Rev., 55(3):329-347. [doi:10.1016/S0169409X(02)00228-4]

Parmentier, C., Gardet, P., 1994. The use of 32 phosphorus $\left({ }^{32} \mathrm{P}\right)$ in the treatment of polycythemia vera. Nouvelle Revue Française D'hématologie, 36(2):189-192.

Patel, S.J., Shapiro, W.R., Laske, D.W., et al., 2005. Safety and feasibility of convection-enhanced delivery of Cotara for the treatment of malignant glioma: initial experience in 51 patients. Neurosurgery, 56(6):1243-1253. [doi:10. 1227/01.NEU.0000159649.71890.30]

Perkins, A., Hilson, A., Hall, J., 2008. Global shortage of medical isotopes threatens nuclear medicine services. $B M J, 337: a 1577$. [doi:10.1136/bmj.a1577]

Perkins, A.C., Vivian, G., 2009. Molybdenum supplies and nuclear medicine services. Nucl. Med. Commun., 30(9): 657-659. [doi:10.1097/MNM.0b013e32832da2770000 6231-200909000-00001]

Pillai, M.R., Knapp, F.F.R.Jr., 2011. Overcoming the ${ }^{99 \mathrm{~m}} \mathrm{Tc}$ shortage: are options being overlooked? J. Nucl. Med., 52(2): $15 \mathrm{~N}-28 \mathrm{~N}$.

Pini, A., Viti, F., Santucci, A., et al., 1998. Design and use of a phage display library. Human antibodies with subnanomolar affinity against a marker of angiogenesis eluted from a two-dimensional gel. J. Biol. Chem., 273(34): 21769-21776. [doi:10.1074/jbc.273.34.21769]

Pons, F., Herranz, R., Garcia, A., et al., 1997. Strontium-89 for palliation of pain from bone metastases in patients with prostate and breast cancer. Eur. J. Nucl. Med., 24(10): 1210-1214. [doi:10.1007/s002590050143]

Pressman, D., Korngold, L., 1953. The in vivo localization of anti-Wagner-osteogenic-sarcoma antibodies. Cancer, 6(3):619-623. [doi:10.1002/1097-0142(195305)6:3<619:: AID-CNCR2820060319>3.0.CO;2-Y]

Qaim, S.M., 2001. Therapeutic radionuclides and nuclear data. Radiochim. Acta, 89(4-5):297-302. [doi:10.1524/ract. 2001.89.4-5.297] 
Qaim, S.M., Tarkanyi, F., Capote, R., 2011. Nulcear data for the production of therapeutic radionuclides. International Atomic Energy Agency, Vienna, Austria.

Rasulova, N., Lyubshin, V., Arybzhanov, D., et al., 2013. Effectiveness of bone metastases treatment by Sm-153 oxabifore in combination with monoclonal antibody denosumab (Xgeva): first experience. World J. Nucl. Med., 12(1):19-23. [doi:10.4103/1450-1147.113942]

Rhodes, B.A., Lambert, C.R., Marek, M.J., et al., 1996. Re-188 labelled antibodies. Appl. Radiat. Isot., 47(1): 7-14. [doi:10.1016/0969-8043(95)00262-6]

Sahoo, S.K., Parveen, S., Panda, J.J., 2007. The present and future of nanotechnology in human health care. Nanomed. Nanotechnol. Biol. Med., 3(1):20-31. [doi:10.1016/j.nano. 2006.11.008]

Sainz-Esteban, A., Baum, R.P., 2013. Successful treatment of metastasized pancreatic vasoactive intestinal polypeptidesecreting tumor unresponsive to high-dose octreotide by peptide receptor radionuclide therapy using ${ }^{90} \mathrm{Y}$ DOTA TATE. Clin. Nucl. Med., 38(12):996-997. [doi:10.1097/ RLU.0b013e3182a7596b00003072-201312000-00018]

Schliemann, C., Wiedmer, A., Pedretti, M., et al., 2009. Three clinical-stage tumor targeting antibodies reveal differential expression of oncofetal fibronectin and tenascin-C isoforms in human lymphoma. Leuk. Res., 33(12): 1718-1722. [doi:10.1016/j.leukres.2009.06.025]

Schmaljohann, D., 2006. Thermo- and pH-responsive polymers in drug delivery. Adv. Drug Deliv. Rev., 58(15): 1655-1670. [doi:10.1016/j.addr.2006.09.020]

Schneider, P., Farahati, J., Reiners, C., 2005. Radiosynovectomy in rheumatology, orthopedics, and hemophilia. $J$. Nucl. Med., 46(S1):48S-54S.

Schultz, C.C., Campbell, J., Bakalyar, D., et al., 2009. Y-90 microsphere therapy: prevention of adverse events. Cancer Biother. Radiopharm., 24(4):427-433. [doi:10. 1089/cbr.2008.0595]

Sgouros, G., 1993. Bone marrow dosimetry for radioimmunotherapy: theoretical considerations. J. Nucl. Med., 34(4):689-694.

Shamim, S.A., Kumar, R., Halanaik, D., et al., 2010. Role of rhenium-188 tin colloid radiosynovectomy in patients with inflammatory knee joint conditions refractory to conventional therapy. Nucl. Med. Commun., 31(9): 814-820. [doi:10.1097/MNM.0b013e32833d6869]

Silberstein, E.B., 1979. Radionuclide therapy of hematologic disorders. Semin. Nucl. Med., 9(2):100-107.

Srivastava, S.C., 2012. Paving the Way to Personalized Medicine: Production of Some Promising Theragnostic Radionuclides at Brookhaven National Laboratory. Seminars in Nuclear Medicine, Elsevier.

Stabin, M.G., Eckerman, K.F., Bolch, W.E., et al., 2002. Evolution and status of bone and marrow dose models. Cancer Biother. Radiopharm., 17(4):427-433. [doi:10. 1089/108497802760363213]

Tavintharan, S., Sundram, F.X., Chew, L.S., 1997. Radioiodine (I-131) therapy and the incidence of hypothyroidism. Ann. Acad. Med. Singap., 26(1):128-131.
Teunissen, J.J., Kwekkeboom, D.J., Kooij, P.P., et al., 2005. Peptide receptor radionuclide therapy for non-radioiodineavid differentiated thyroid carcinoma. J. Nucl. Med., 46(S1):107S-114S.

Thamboo, T., Tan, K.B., Wang, S.C., et al., 2003. Extrahepatic embolisation of Y-90 microspheres from selective internal radiation therapy (SIRT) of the liver. Pathology, 35(4):351-353. [doi:10.1080/0031302031000152892]

Tomblyn, M., 2012. The role of bone-seeking radionuclides in the palliative treatment of patients with painful osteoblastic skeletal metastases. Cancer Control., 19(2): 137-144.

Toohey, R.E., Stabin, M.G., Watson, E.E., 2000. The AAPM/RSNA physics tutorial for residents. Internal radiation dosimetry: principles and applications1 (CME available in print version and on RSNA Link). Radiographics, 20(2):533-546. [doi:10.1148/radiographics.20. 2.g00mc33533]

Torchilin, V.P., 2005. Recent advances with liposomes as pharmaceutical carriers. Nat. Rev. Drug Discov., 4(2): 145-160. [doi:10.1038/nrd1632]

Tripepi, G., Mattace Raso, F., Sijbrands, E., et al., 2011. Inflammation and asymmetric dimethylarginine for predicting death and cardiovascular events in ESRD patients. Clin. J. Am. Soc. Nephrol., 6(7):1714-1721. [doi:10.2215/ CJN.11291210]

Troutner, D.E., 1987. Chemical and physical properties of radionuclides. Int. J. Radiat. Appl. Instrument. Part B. Nucl. Med. Biol., 14(3):171-176. [doi:10.1016/08832897(87)90039-0]

Turkmen, C., Ozturk, S., Unal, S.N., et al., 2007. Monitoring the genotoxic effects of radiosynovectomy with Re-186 in paediatric age group undergoing therapy for haemophilic synovitis. Haemophilia, 13(1):57-64. [doi:10. 1111/j.1365-2516.2006.01406.x]

Ugur, O., Gedik, G.K., Atilla, B., et al., 2008. Radiosynovectomy: current status in the management of arthritic conditions. Nucl. Med. Commun., 29(9):755-758. [doi:10. 1097/MNM.0b013e3283023f9e]

Valkema, R., Pauwels, S., Kvols, L.K., et al., 2006. Survival and response after peptide receptor radionuclide therapy with $\left[{ }^{90} \mathrm{Y}\right.$-DOTA $\left.{ }^{0}, \mathrm{Tyr}^{3}\right]$ octreotide in patients with advanced gastroenteropancreatic neuroendocrine tumors. Semin. Nucl. Med., 36(2):147-156. [doi:10.1053/j. semnuclmed.2006.01.001]

Vandergrift, W.A., Patel, S.J., 2006. Convection-enhanced delivery of immunotoxins and radioisotopes for treatment of malignant gliomas. Neurosurg. Focus, 20(4):E13. [doi:10.3171/foc.2006.20.4.8]

vande Streek, P., Carretta, R., Weiland, F.L., 1994. Bone pain and radionuclide therapy. West J. Med., 161(4):409.

Villa, A., Trachsel, E., Kaspar, M., et al., 2008. A high-affinity human monoclonal antibody specific to the alternatively spliced EDA domain of fibronectin efficiently targets tumor neo-vasculature in vivo. Int. J. Cancer, 122(11): 2405-2413. [doi:10.1002/ijc.23408]

Volkert, W.A., Goeckeler, W.F., Ehrhardt, G.J., et al., 1991. 
Therapeutic radionuclides: production and decay property considerations. J. Nucl. Med., 32(1):174-185.

Weber, D., Eckerman, K., Dillman, L.T., et al., 1989. MIRD: radionuclide Data and Decay Scheme. Society of Nuclear Medicine, New York.

Weiner, R.E., Thakur, M.L., 2005. Radiolabeled peptides in oncology: role in diagnosis and treatment. BioDrugs, 19(3): 145-163. [doi:10.2165/00063030-200519030-00002]

Werner, S.C., Coelho, B., Quimby, E.H., 1957. Ten year results of I-131 therapy of hyperthyroidism. Bull. N. Y. Acad. Med., 33(11):783-806.

Williams, L.E., DeNardo, G.L., Meredith, R.F., 2008. Targeted radionuclide therapy. Med. Phys., 35(7):3062-3068. [doi:10.1118/1.2938520]

Witzig, T.E., Gordon, L.I., Cabanillas, F., et al., 2002. Randomized controlled trial of yttrium-90-labeled ibritumomab tiuxetan radioimmunotherapy versus rituximab immunotherapy for patients with relapsed or refractory low-grade, follicular, or transformed B-cell non-Hodgkin's lymphoma. J. Clin. Oncol., 20(10):2453-2463. [doi:10. 1200/JCO.2002.11.076]

Wu, L., Yang, Y.F., Ge, N.J., et al., 2012. Hepatic artery injection of ${ }^{131}$ I-labelled metuximab combined with chemoembolization for intermediate hepatocellular carcinoma: a prospective nonrandomized study. Eur. J. Nucl. Med. Mol. Imaging, 39(8):1306-1315. [doi:10.1007/ s00259-012-2145-5]

Zaknun, J.J., Bodei, L., Mueller-Brand, J., et al., 2013. The joint IAEA, EANM, and SNMMI practical guidance on peptide receptor radionuclide therapy (PRRNT) in neuroendocrine tumours. Eur. J. Nucl. Med. Mol. Imaging, 40(5):800-816. [doi:10.1007/s00259-012-2330-6]

Zweit, J., 1996. Radionuclides and carrier molecules for therapy. Phys. Med. Biol., 41(10):1905. [doi:10.1088/ 0031-9155/41/10/004]

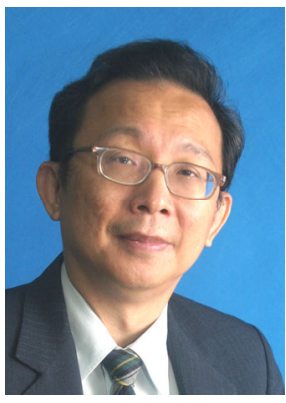

Introducing editorial board member:

Dr. Kwan-Hoong NG, the author of this invited review, is an editorial board member of Journal of Zhejiang UniversitySCIENCE B (Biomedicine \& Biotechnology).

Dr. $\mathrm{Ng}$ is a professor at the Department of Biomedical Imaging, University of Malaya, Malaysia. He is certified by the American Board of Medical Physicist. In 2013, he was honored as one of the top 50 medical physicists in the world by the International Organization of Medical Physics. He has authored/coauthored over 200 papers in peer-reviewed journals and 20 book chapters, and co-edited 5 books. He has presented over 500 scientific papers; more than 300 are invited lectures. His main research contribution has been in the biophysical characterization of breast diseases, radiation dosimetry, risk communication, and development of novel diagnostic tools.

Dr. Ng has been serving as an International Atomic Energy Agency (IAEA) expert and as a consulting expert for the International Commission on Non-Ionizing Radiation Protection. He is the founding president of the South East Asian Federation of Medical Physics and is the immediate president of the Asia-Oceania Federation of Organizations for Medical Physics.

\section{中文概要:}

\section{本文题目: 核医学放射性核素治疗的研究现状及前景}

Therapeutic radionuclides in nuclear medicine: current and future prospects

本文目的：本文综述了临床常用的放射性治疗方式和应用现状以及新的放射性核素从科研至临床应用所 存在的问题。

本文概要: 放射性核素的临床应用及研究已历数十载, 已有碘-131、磷-32、锶-90 及钇-90 等众多放射性 核素被成功用于治疗良恶性疾病。随着新的放射性核素及药物不断应用于骨转移瘤疼痛治疗、 神经内分泌肿瘤及其他良恶性肿瘤治疗，放射性核素治疗得到了快速发展。目前，放射性核 素治疗已进入蓬勃发展期; 在亚洲, 由于甲状腺和肝脏肿瘤的高发病率, 促进了放射性核素 治疗及其靶向治疗研究的日益发展。随着放射性核素与其他药物的联合应用, 放射性核素治 疗肿瘤的临床价值必将显著提高。

关键词组: 核医学; 核素治疗; 靶向治疗; 放射性药物; 放射性核素治疗 